TECTONICS, VOL. 10, NO. 5, PAGES 1018-1037, OCTOBER 1991

\section{CRUSTAL STRUCTURE AND THE MECHANISM OF EXTENSION IN THE NORTHERN RED SEA: CONSTRAINTS FROM GRAVITY ANOMALIES}

\author{
James R. Cochran \\ Lamont-Doherty Geological Observatory of \\ Columbia University, Palisades, New York \\ Jean-Michel Gaulier ${ }^{1}$ and Xavier Le Pichon \\ Département de Géologie, Ecole Normale \\ Supérieure, Paris, France
}

\begin{abstract}
Gravity data from detailed marine surveys were used to investigate the density structure of the crust and upper mantle beneath the northern Red Sea, a continental rift considered by many to be in the process of establishing a mid-ocean ridge type spreading center. A gravity and bathymetry profile across the sea near $27^{\circ} \mathrm{N}$ was analyzed in detail. Model constraints include single-channel and multichannel seismic reflection lines coincident with the gravity profile, which provide detailed information on sedimentary layers, a series of ESP seismic experiments centered nearly on the gravity line which constrain the sediment and crustal thickness, and a series of 58 closely spaced heat flow measurements nearly coincident with the gravity line which closely constrain the mantle thermal structure and thus density variations within the mantle. The calculated gravity anomalies based on the known crustal and mantle structure fail to match the observed data. Specifically, the model anomalies become steadily more negative from the margins toward the center of the sea with the result that the calculated gravity is approximately $25 \mathrm{mGal}$ more negative near the axis relative to the marginal areas than are the observed anomalies. Two possible solutions were investigated. One is to introduce a lower crustal layer resulting from crustal underplating within what was originally considered to be the upper mantle beneath the marginal areas. The other is to introduce an area of slightly denser crust resulting from intrusion of new mafic crustal material within the axial depression. Both solutions can reproduce the observed gravity anomalies within the Red Sea. However, the complete set of geophysical data, and in particular the heat flow in the Red Sea and gravity and seismic refraction data on land, suggests that the most satisfactory model is that the crust of the axial depression is denser than that of the marginal areas. This implies that crustal extension in the northern Red Sea is presently occurring in large part by intrusion of new mafic material.
\end{abstract}

\footnotetext{
1 now at Institut Francais du Pétrole, Rueil Malmaison, France.
}

Copyright 1991 by the American Geophysical Union.

Paper number 91TC00926.

0278-7407/91/91TC-00926\$10.00

\section{INTRODUCTION}

The northern Red Sea (Figure 1) is a unique location to study lithospheric rifting, the structural and sedimentological development of a "passive" continental margin, and the initiation of seafloor spreading within a continental rift for the simple reason that these processes are presently occurring there. A number of detailed geological and geophysical studies [Pautot et al., 1984, 1986; Cochran et al., 1986; Martínez and Cochran, 1988, 1989; Cochran and Martínez, 1988; Gaulier et al., 1988; Le Pichon and Gaulier, 1988; Guennoc et al., 1988, 1990] have recently been carried out in the area and have provided a great deal of new geophysical data in the northem Red Sea. The purpose of this paper is to use these new data (bathymetry, single-channel and multichannel seismic reflection, seismic refraction, gravity, and heat flow) to constrain gravity models of the northern Red Sea in order to determine the density structure of the crust and mantle beneath it and to investigate the processes by which lithospheric expansion is presently occurring.

\section{DESCRIPTION OF DATA}

A track chart showing the location of available marine geophysical data in the northern Red Sea is shown in Figure 2. The data are primarily from $R / V$ Robert $D$. Conrad cruise 2507 and from a detailed survey of the former Exxon Safaga concession. Figure 3 shows a bathymetry map of the northern Red Sea, contoured at $100 \mathrm{~m}$ intervals, and Figure 4 shows a free-air gravity anomaly map with a 10 mGal contour interval, both based on these data.

The geophysical profile chosen for analysis is shown in Figure 5. The location of the profile is shown in Figure 2 and is superimposed on the bathymetry (Figure 3) and free-air gravity (Figure 4) maps. Data available along this line include bathymetry (Seabeam and conventional $12 \mathrm{kHz}$ echosoundings), free-air gravity anomalies, total intensity magnetic anomalies and single-channel seismic reflection profiles utilizing a watergun source (Figure 6 ). These data were obtained during R/V Robert $D$. Conrad cruise 2507 in June 1984. The bathymetry data in Figure 5 are Seabeam center-beam data. Gravity anomalies were measured using a Bell BGM-3 gravimeter [Bell and Watts, 1986] and navigation during the survey was by Loran-C supplemented by transit satellite fixes. Gravity crossover errors are less than about $1 \mathrm{mGal}$ for Loran-C navigated portions of the Conrad survey and less than about $3 \mathrm{mGal}$ in the worst cases. The entire line considered in this study utilized Loran navigation. Our line is the "Central Heat Flow Line" of Martinez and Cochran [1988] and was run directly over a series of $\mathbf{5 8}$ heat flow measurements. The heat flow measurements are spaced 1-2 km apart and form one of three heat flow traverses across the Red Sea collected during the Conrad cruise [Martínez and Cochran, 1989]. More details concerning the data acquisition and reduction are given by Martínez and Cochran [1988]. 


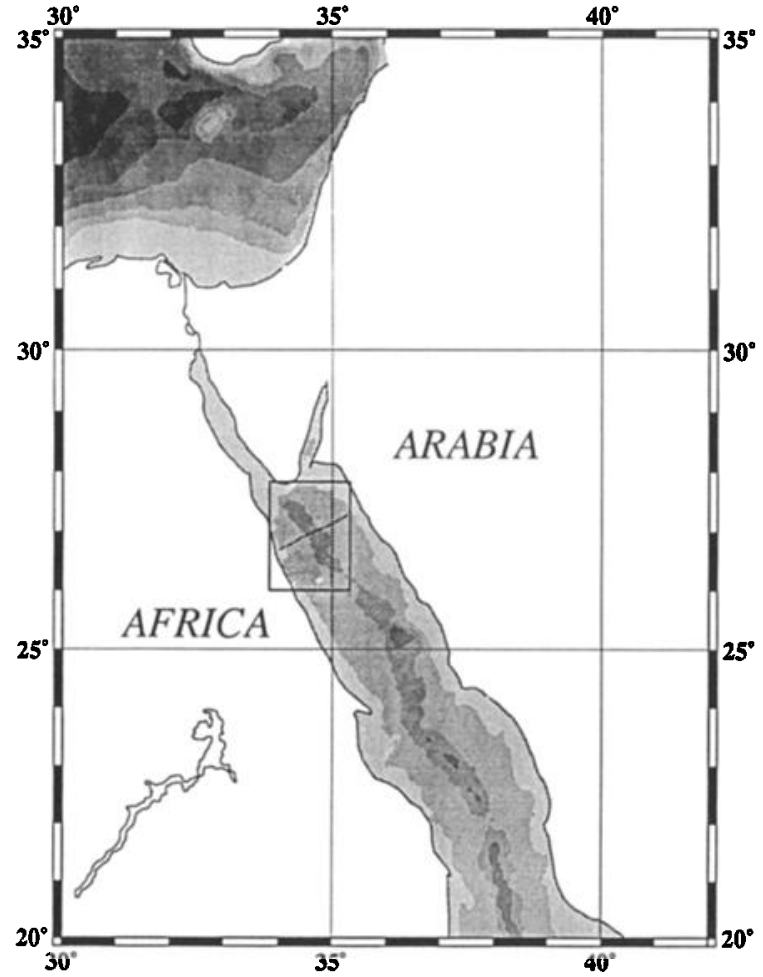

The western half of the line coincides with multichannel seismic reflection line ERS 74 published by Barakat and Miller [1984] and Miller and Barakat [1988], which was made available to us by Esso Exploration Company. Although the basement was not imaged on this line, it is possible to identify the top and bottom of the Miocene evaporites along much of the seismic line [Martínez and Cochran, 1988]. These horizons were digitized for use in the gravity modeling. We also used marine gravity and bathymetry data from the western end of the Exxon line to extend the Conrad profile closer to shore.

Control on the depth to igneous basement and on the crustal thickness within the northern Red Sea is provided by a series of Expanding Spread Profile (ESP) seismic experiments carried out by a consortium of French institutions during the the Minos expedition in 1986 [Gaulier et al, 1988]. The Minos

Fig, 1. Map of the northern Red Sea region. Water-covered areas are shaded with the intensity of shading increasing at $500 \mathrm{~m}$ depth intervals. Box outlines the area of the gravity map shown in Figure 4. The location of the gravity and bathymetry profile (Figure 5) interpreted in this study is also shown.

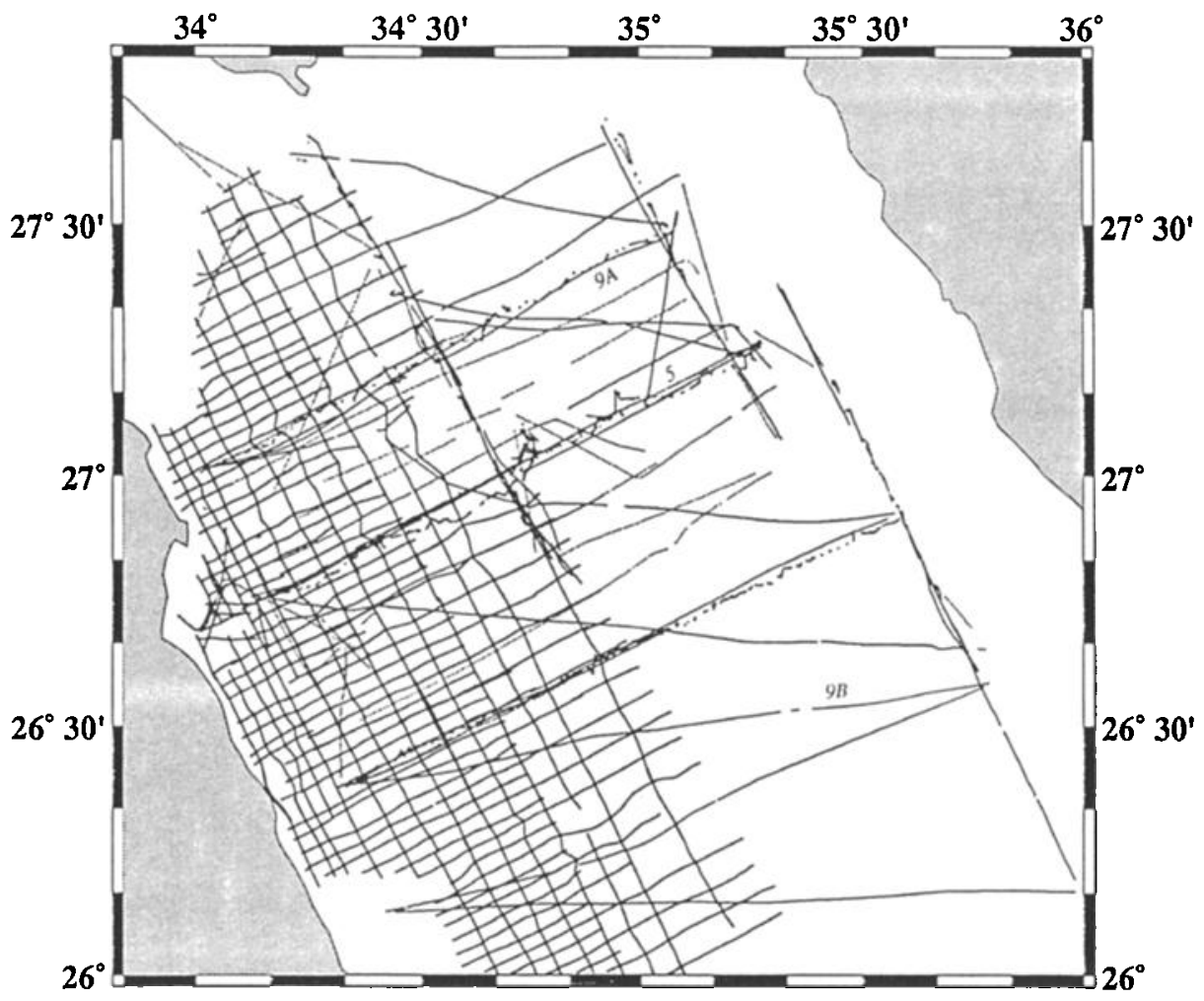

Fig. 2. Map of the northern Red Sea showing the location of data used to construct the free-air gravity map shown in Figure 4. Each dot shows the location of a gravity measurement. The total number of data points is 130,212 . The distribution of bathymetry data used to construct the map shown in Figure 3 is nearly identical. Location of lines shown in Figures 5 and 9 are also indicated. 
experiment consisted of 15 ESPs using an air gun source and a $2.4 \mathrm{~km}$ long, 96 channel streamer. Navigation during the seismic experiments was by Loran-C and transit satellites with the distance between the two ships determined using a Syledis system. In general, clear refracted mantle arrivals were obtained on lines near the coast. On the lines further out in the Red Sea, Gaulier et al. [1988] determined the depth to Moho from reflection hyperbolae. Four of the ESPs (ESPs 3-6) form a profile from the Egyptian coast to the axis between $26^{\circ} 20^{\prime} \mathrm{N}$ and $27^{\circ} 20^{\prime} \mathrm{N}$ (Figures 3 and 4). The individual ESPs are oriented NW-SE along the strike of the Red Sea and are spaced about $20 \mathrm{~km}$ apart. The Conrad gravity line is located near the midpoints of these four lines. Crustal columns for the ESPs are shown in Figure 7. See Gaulier et al. [1988] for more details on the processing and interpretation of these seismic lines.

Additional control for the onshore regions is provided by geophysical studies in Egypt. These data include heat flow measurements published by Morgan et al. [1980, 1985], seismic refraction experiments carried out by the Institute of Geophysics of the University of Hamburg [Makris et al., 1982; Rihm and Makris, 1989; Hosney, 1985], and gravity data in Egypt obtained through the Bureau Gravimetrique International (Figure 8). Other than seismic refraction experiments near the coast [Makris et al., 1983], very few geophysical data are available in northwestern Saudi Arabia.

\section{STRUCTURE OF THE NORTHERN RED SEA}

The portion of the northern Red Sea north of $26^{\circ} \mathrm{N}$ has been the subject of a number of recent geophysical studies [Cochran et al., 1986; Martínez and Cochran, 1988, 1989; Guennoc et al., 1988, 1990; Gaulier et al., 1988; Le Pichon and Gaulier, 1988; Cochran and Martínez, 1988] and its morphology and structure are reasonably well known. The northern Red Sea consists of narrow continental shelves and a broad main trough (Figures 3 and 5). The main trough is conveniently divided into "marginal areas", which actually occupy most of the width of the sea, and an "axial depression" $15-30 \mathrm{~km}$ wide [Cochran et al., 1986; Martínez and Cochran, 1988; Guennoc et al., 1988] (Figures 3 and 5).

The bathymetry of the marginal areas forms a series of terraces or levels $20-30 \mathrm{~km}$ wide which are generally at depths of about $500 \mathrm{~m}, 800 \mathrm{~m}$, and 950 $\mathrm{m}$ (Figures 3 and 5). These terraces are separated by areas of steeper slopes or, in some places, by steep escarpments which sometimes appear to be fault controlled. The terraces have irregular surfaces with local relief of the order of 50-100 m which appears in many places to be related to salt tectonics (Figure 6). The top of the evaporite layer is a prominent reflector labeled "S" in Figure 6.

The axial depression is a region of deep water $1100-1300 \mathrm{~m}$ deep and from 15 to $30 \mathrm{~km}$ wide occupying the central portion of the northern Red Sea [Cochran et al., 1986]. The axial depression differs

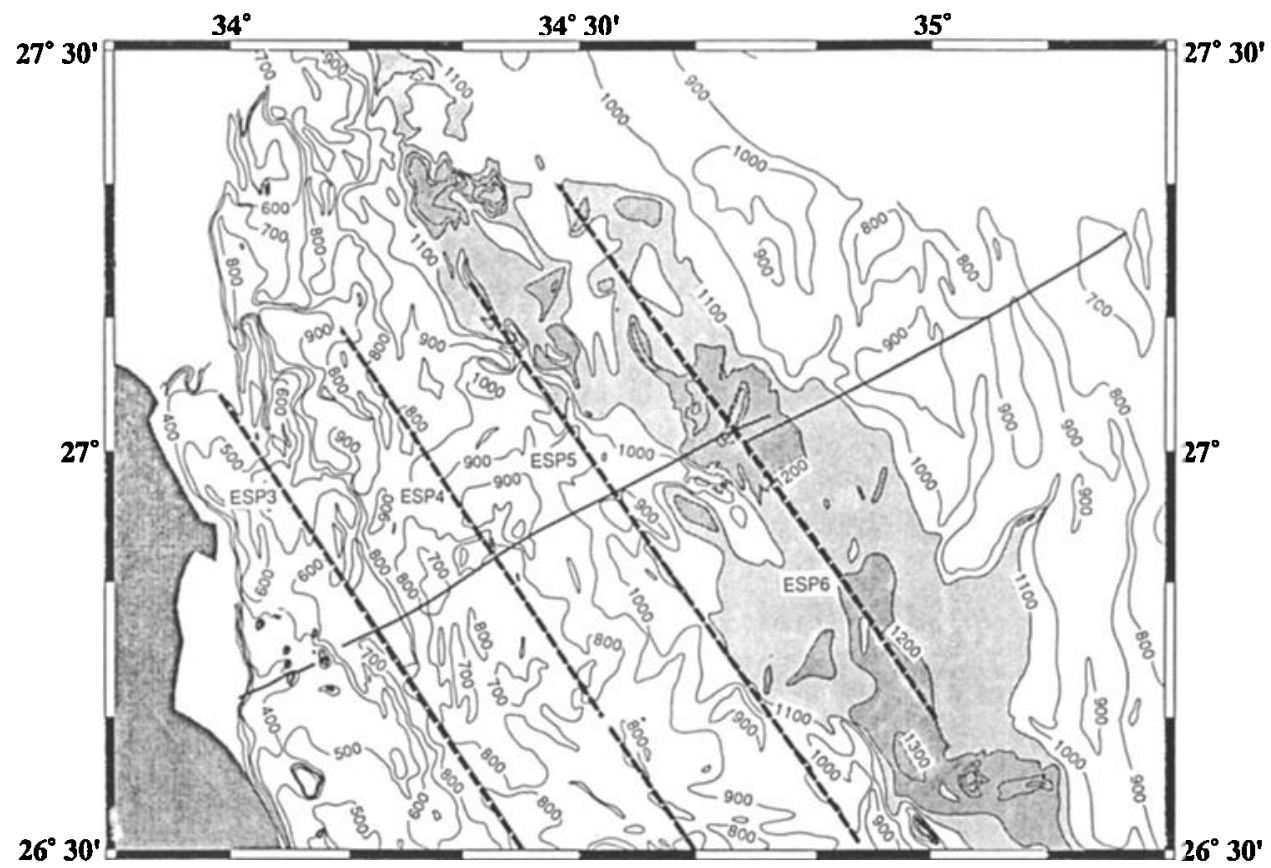

Fig. 3. Bathymetry map of the northern Red Sea near $27^{\circ} \mathrm{N}$ based on data from Conrad cruise 25-07 and Exxon's Safaga Concession survey (see Figure 2 for location of data). Contour interval is $100 \mathrm{~m}$. Areas deeper than $1100 \mathrm{~m}$ are shaded light grey, and areas deeper than $1200 \mathrm{~m}$ are shaded dark grey. Solid line shows ship tracks for the profiles shown in Figures 5 and 6 . Heavy dashed lines show the locations of the northern set of Minos ESP experiments (Figure 7a). 


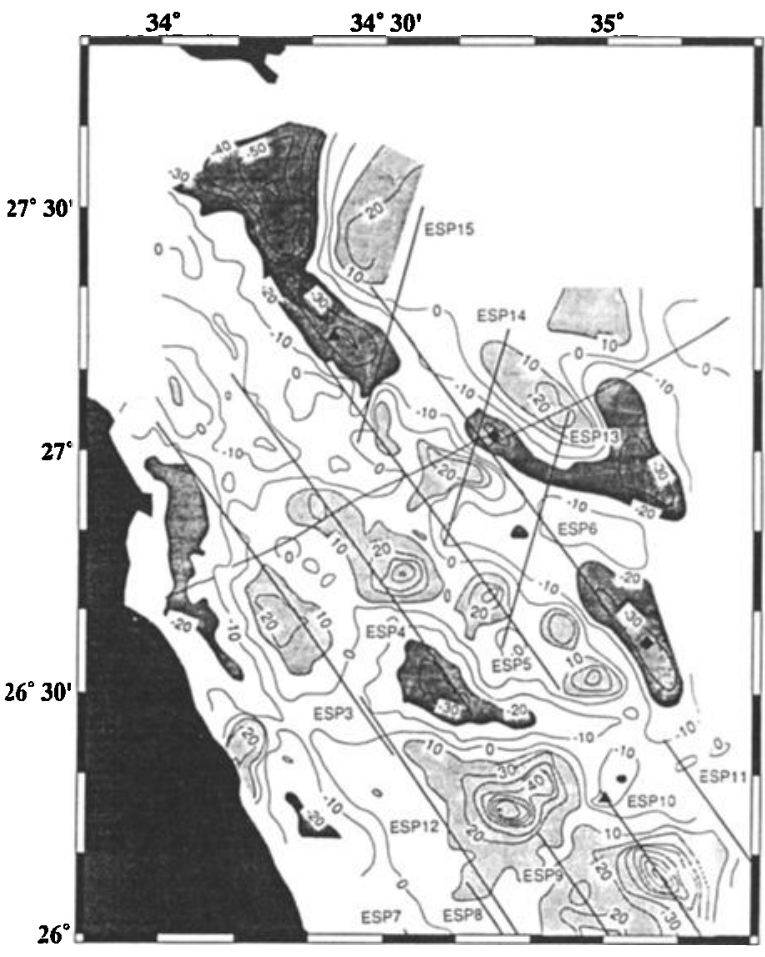

Fig. 4. Free-air gravity anomaly map of the northwestern Red Sea, based on data from Conrad cruise 25-07 and Exxon's Safaga Concession survey (See Figure 2 for location of data). Contour interval is 10 mGal. Regions more positive than $+10 \mathrm{mGal}$ are shaded light grey, and regions more negative than $-20 \mathrm{mGal}$ are shaded dark grey. Locations of deeps with dipolar magnetic anomalies are shown by diamonds; locations of deeps without magnetic anomalies are shown by triangles. Lighter solid line shows the location of ship tracks for the profiles shown in Figures 5 and 6; heavier solid lines show locations of the Minos ESP experiments. from the oceanic "axial trough" of the southern Red Sea in that sedimentary sequences, including both the post-Miocene pelagic sediments and the Miocene evaporites, are continuous across it (see Figure 6), lineated magnetic anomalies are not present, and it is shallower. The axial depression sometimes, although not always, appears to be fault bounded. It is marked by a free-air gravity minimum with a relative amplitude of 30-60 mGal (Figures 4 and 5) and is the location of the maximum heat flow on each of the Conrad heat flow traverses [Cochran and Martínez, 1988; Martínez and Cochran, 1989].

The marginal areas and the axial depression also vary markedly in the pattern of deformation observed in the sediments [Martínez and Cochran, 1988]. Seismic reflection data show that the marginal areas are affected by a combination of salt tectonics and widely spaced faulting. Deformation in the axial depression is more intense and concentrated and frequently extends to the seafloor. Martínez and Cochran [1988] argue that the extension became primarily focused in the axial depression at some time after deposition of reflector $S$.

The axial depression is not only the locus of recent deformation, but is also the location of a series of axial deeps spaced at 50-75 km intervals along it (see Figures 3 and 4). Those within the well-surveyed area north of $26^{\circ} \mathrm{N}$ include Conrad Deep just north of $27^{\circ} \mathrm{N}$ [Cochran et al., 1986], an unnamed deep at $26^{\circ} 36^{\prime} \mathrm{N}$ [Pautot et al., 1986], and Shaban (or Jean Charcot) Deep near $26^{\circ} 15^{\prime} \mathrm{N}$ [Pautot et al., 1984]. In addition, another unnamed deep was reported by Guennoc et al. [1988] at about $25^{\circ} 42^{\prime} \mathrm{N}$. These are all small northern Red Sea type deeps, most of which are associated with large, normally magnetized, dipolar magnetic anomalies, which presumably result from fairly recent, localized intrusions [Cochran et al,. 1986]. A volcanic ridge can be observed at Shaban Deep [Pautot et al., 1984).

The axial depression is particularly well developed on our profile (Figure 5). It is approximately $25 \mathrm{~km}$

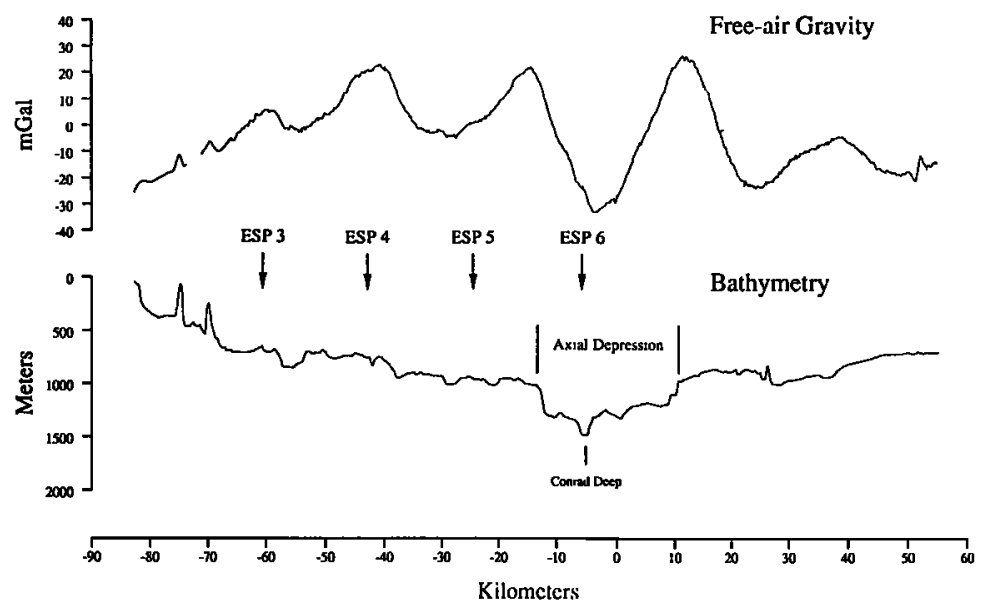

Fig. 5. Bathymetry and free-air gravity anomaly profile across the Red Sea near $27^{\circ} \mathrm{N}$ which is modeled in detail in this study The profile is projected along an azimuth of $\mathrm{N} 50^{\circ} \mathrm{E}$. Location of the profile is shown in Figures 2,3 , and 4 . The projected locations of the centers of ESP lines 3-6 are also shown. 
wide and is bounded by scarps $250-350 \mathrm{~m}$ high which appear to be faulted. The axial depression is also associated with a large negative gravity anomaly with an amplitude of 55 to $65 \mathrm{mGal}$ relative to the flanking highs. The profile passes over the southern end of the Conrad Deep (Figures 3 and 5). Cochran and Martínez [1989] have pointed out that both the negative gravity anomaly associated with the axial depression and the flanking positive anomalies are best developed near the location of axial deeps. However, even away from deeps, at locations where the morphologic expression of the axial depression is subdued, the axis is associated with a large amplitude negative anomaly. This can be seen in Figure 9 which shows two bathymetry and free-air gravity profiles across the Red Sea, crossing the axis about $30 \mathrm{~km}$ north and about $65 \mathrm{~km}$ south of our line (locations shown in Figure 2), where the axial depression is not as well developed. The basement depth at ESP 6 over the axial depression is $8.5 \mathrm{~km}$, assuming that the top of the $5.8 \mathrm{~km} / \mathrm{s}$ layer is the basement. This depth to basement is almost $2 \mathrm{~km}$ greater than that at ESP 5, located outside the axial depression (Figure 7). This observation suggests that the gravity low over the axis is at least in part due to an increased depth to basement.

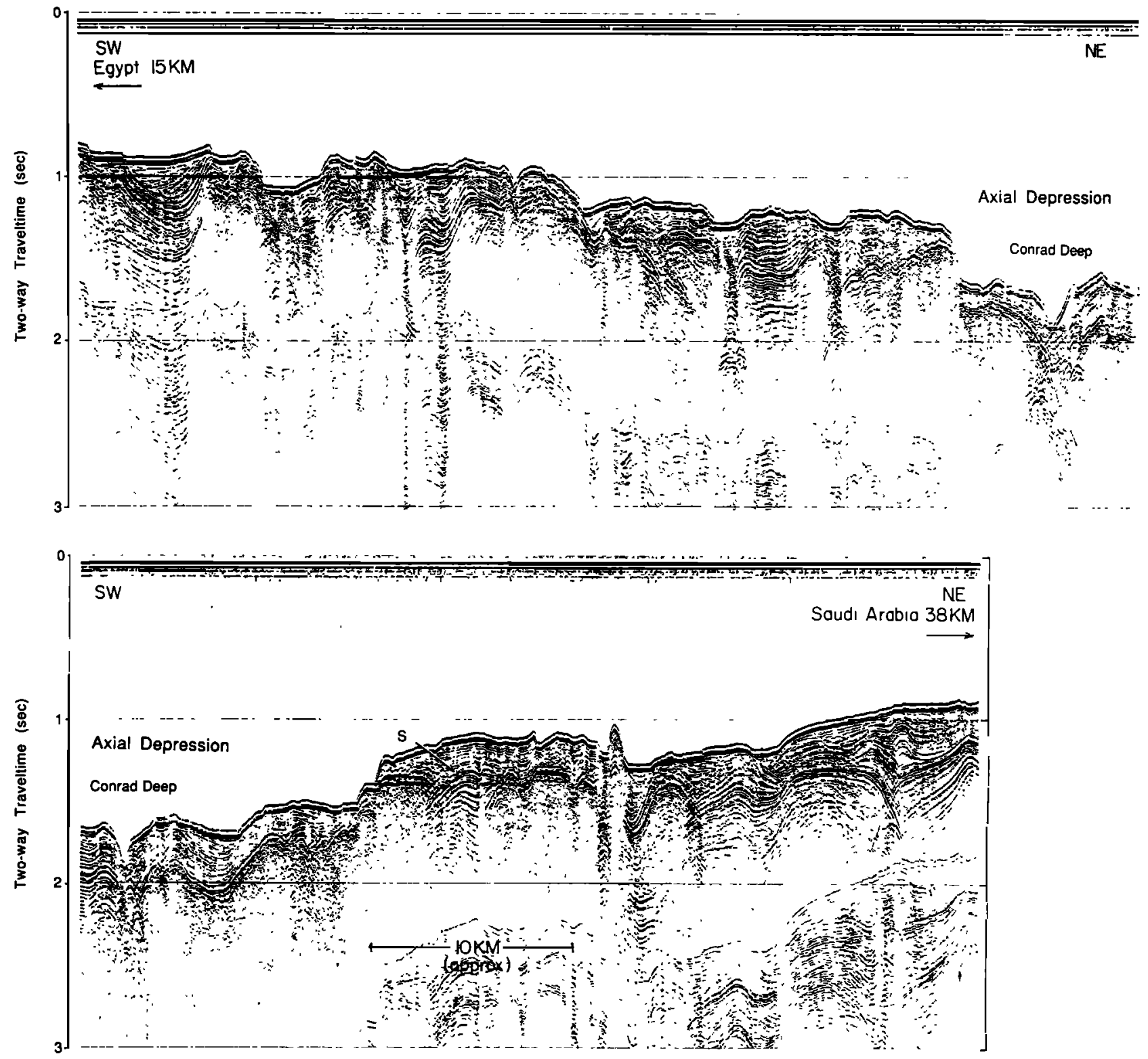

Fig. 6. Single-channel watergun seismic reflection profiles from Conrad cruise 25-07 collected concurrently with the bathymetry and free-air gravity anomaly profile shown in Figure 5. Prominent reflector labeled "S" marks the top of the Miocene evaporite sequence. Locations of the lines are shown in Figures 2, 3 and 4. 


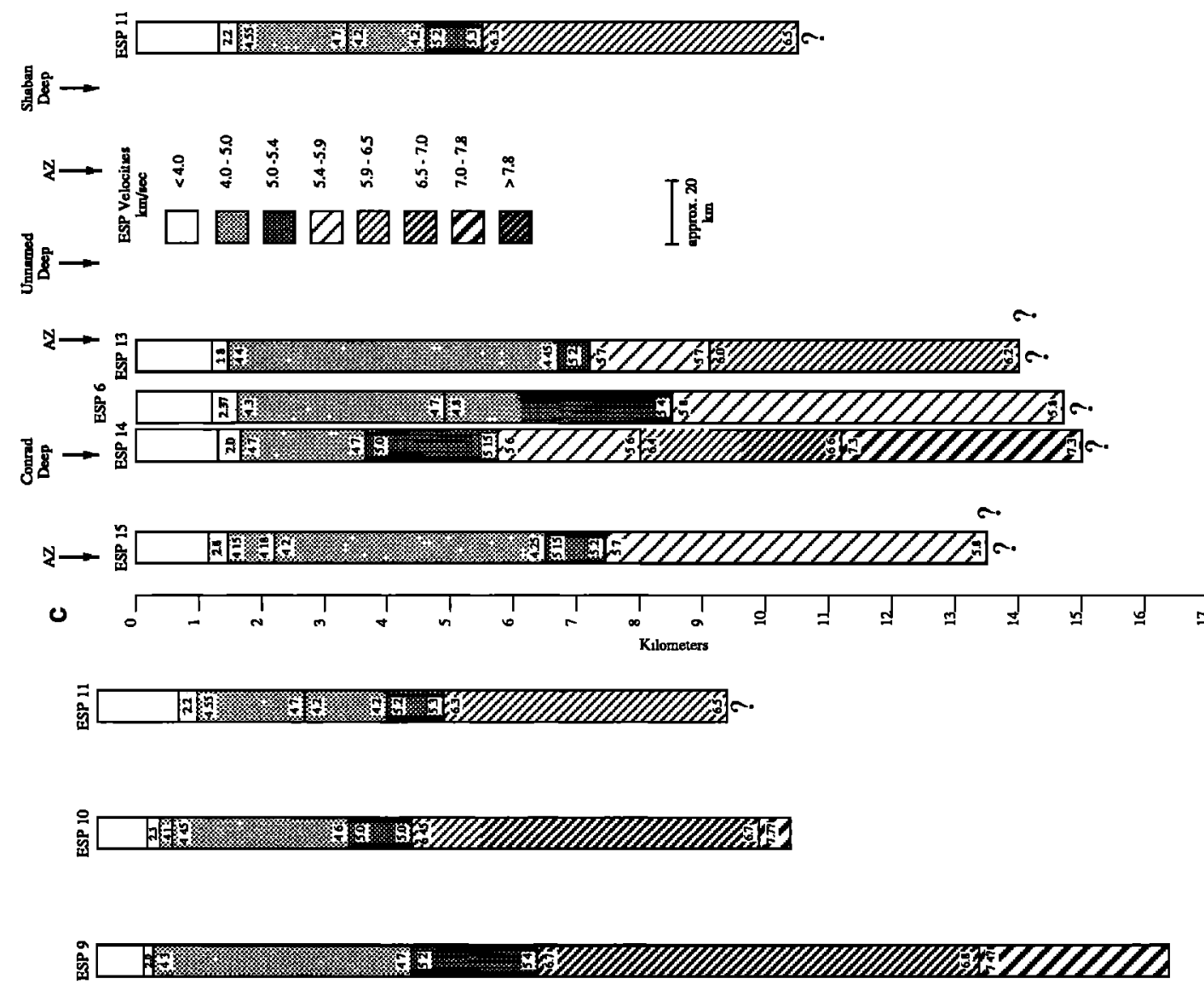

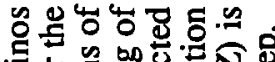

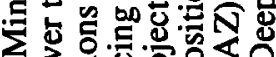
을 过的舟它 过过过 뭉

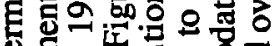

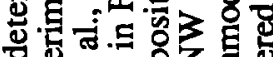

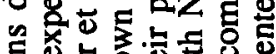

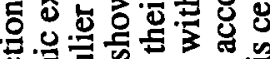

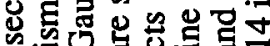

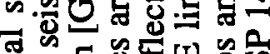

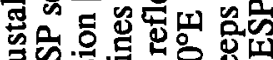

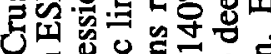
ธ。

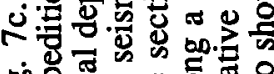

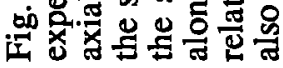

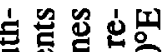
을. ․ㅡㄴ 㲅定

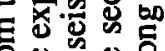

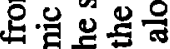

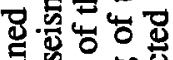
年

공

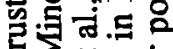

U $\sum_{4}$ 可

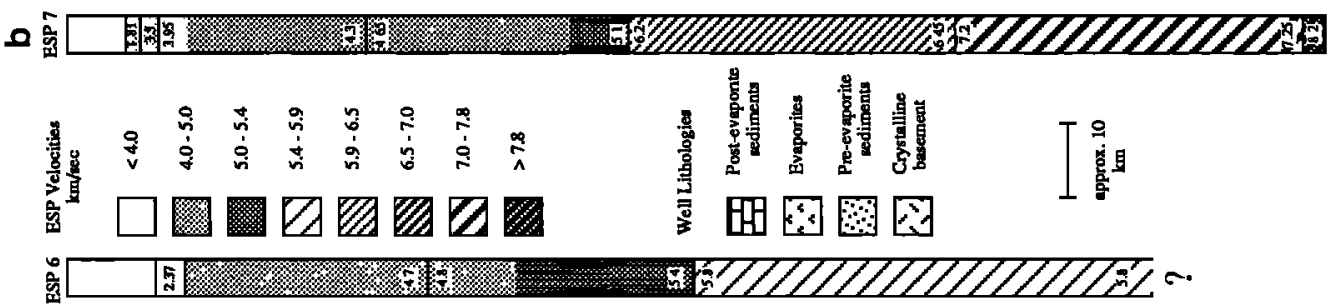

웅

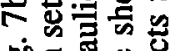

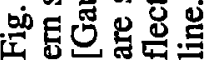

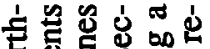
통.

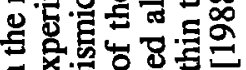
통

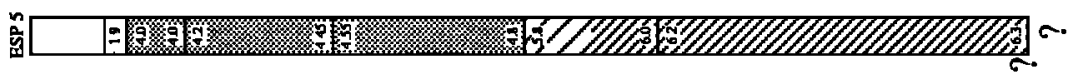

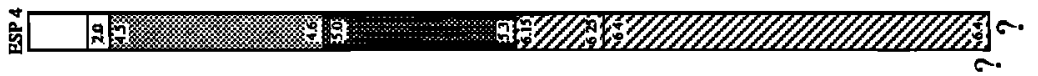

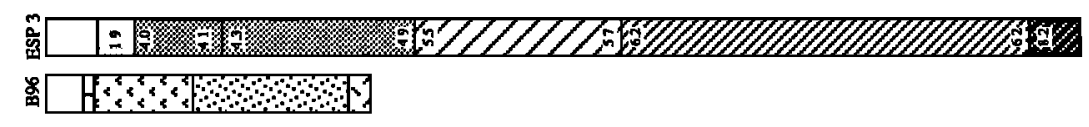

() :

象. 열.

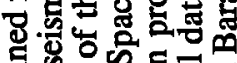

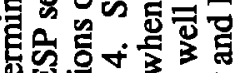

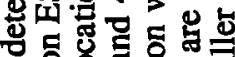
영

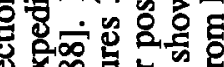
递乐 평. ด้ำ

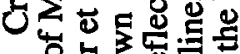
ते

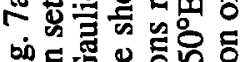

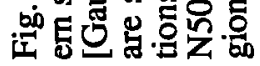



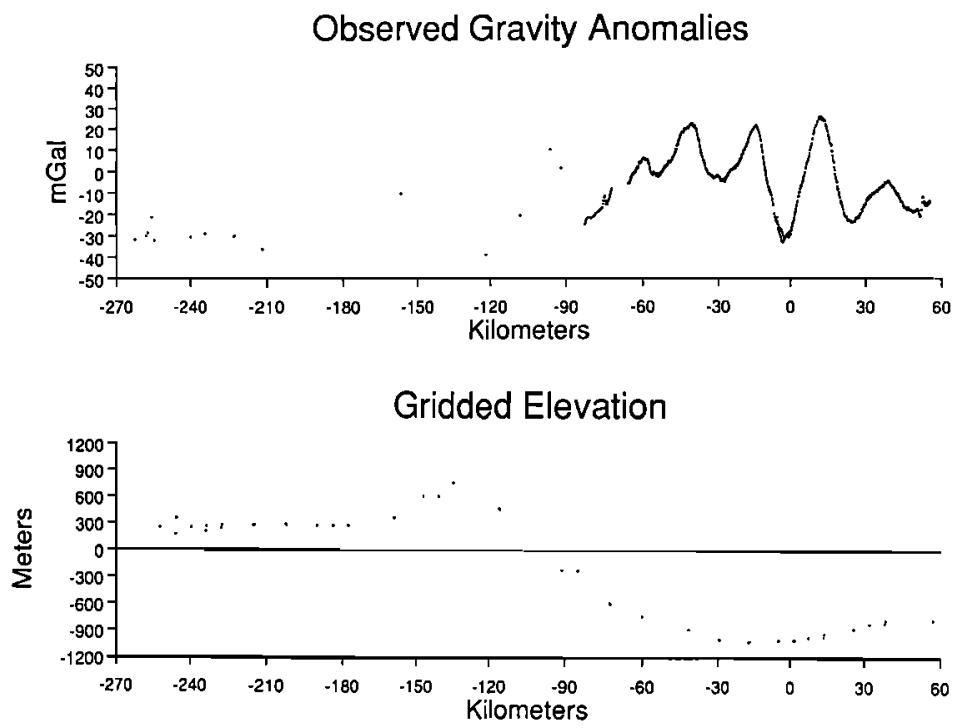

Fig. 8. Topography and gravity anomaly profile extending from the interior of Egypt across the Red Sea. The profile is projected along $N 50^{\circ} \mathrm{E}$, and the coast is at about $\mathrm{km}-90$. Marine data are free-air anomalies from the gravity profile considered in this study (Figure 5). Land data are Bouguer anomalies obtained through the International Gravity Bureau from stations located in a $50 \mathrm{~km}$ wide corridor centered on a continuation of the marine profile. Elevations are $5^{\prime}$ gridded values obtained from the U.S. Defense Mapping Agency's DBDB5 gridded topographic data set.

The increasingly negative gravity anomaly over the axial depression toward $27^{\circ} 35^{\prime} \mathrm{N}$ at the very northern end of the Red Sea (Figure 6) may therefore be interpreted as indicating that the basement deepens toward this location, which is the intersection between the axial depression and the Levant fault zone. Le Pichon and Gaulier [1988] have noted that such triple junctions in oceanic regions are typically characterized by an increase in depth to basement.

The thick mid- to late Miocene evaporite section masks the deeper structure in seismic reflection data. Miller and Barakat [1988] state that seismic reflection data indicate local thicknesses of more than $2100 \mathrm{~m}$ for the evaporites with the thickness increasing toward the axis and to the south. Seismic refraction data [Gaulier et al., 1988] suggest the presence of over $3000 \mathrm{~m}$ of evaporites at places in our study area and about $4000 \mathrm{~m}$ further south. As a result, seismic reflection studies, including extensive multichannel seismic (MCS) surveys run for oil exploration purposes [e.g. Tewfik and Ayyad, 1982; Miller and Barakat, 1988], have consistently failed to image the basement in the northern Red Sea. The top of the evaporites forms a prominent reflector (reflector $\mathbf{S}$ ). Although layering can be seen in places to considerable depth within the evaporites (Figure 6), the base of the evaporite section can only be locally observed on MCS data, and the basement has not been convincingly imaged anywhere in our study area [P. Miller, personal communication, 1985].

The free-air gravity anomalies (Figure 4) form a pattern of elongate highs and lows which are oriented subparallel to the NNW-SSE trend of the rift, and which extend for distances of $50-70 \mathrm{~km}$ along strike.
Free-air gravity highs are systematically located on the seaward edges of the bathymetric terraces. Martínez and Cochran [1988] digitized the seafloor, top of evaporites, and bottom of evaporites from Exxon seismic line ERS 74 in order to determine the extent to which relief on these surfaces can explain the observed gravity anomalies. Martínez and Cochran [1988] conclude that the gravity effect of relief on these observed interfaces does not at all explain the shape or amplitude of the observed gravity which must therefore be due to relief on a deeper surface, presumably the basement, which they interpret as a series of tilted fault blocks $15-30 \mathrm{~km}$ across and roughly $60 \mathrm{~km}$ in length.

Information on the nature of the crust can be obtained from the Minos ESP experiments [Gaulier et al, 1988, see Figure 7]. A total of 15 ESP lines were collected during the expedition. Four of them (ESPs 3-6) form a traverse centered along a line extending from the Egyptian coast near Safaga Island at $26^{\circ} 45^{\prime} \mathrm{N}$ toward Conrad Deep (Figures 3 and 4), with the individual profiles oriented NW-SE along the strike of the rift. The most seaward ESP (ESP 6) is centered over the axial depression just to the south of Conrad Deep. Five ESPs form a similar traverse situated along a line extending from the Egyptian coast near $25^{\circ} 40^{\prime} \mathrm{N}$ toward Shaban Deep. This line thus lies mostly south of our study area. In addition, three ESPs were centered over the axial depression in the northern part of the study area and the final two were collected in the Gulf of Suez.

Gaulier et al. [1988] determined that a thin crust underlies all of the ESPs in the northern Red Sea. 


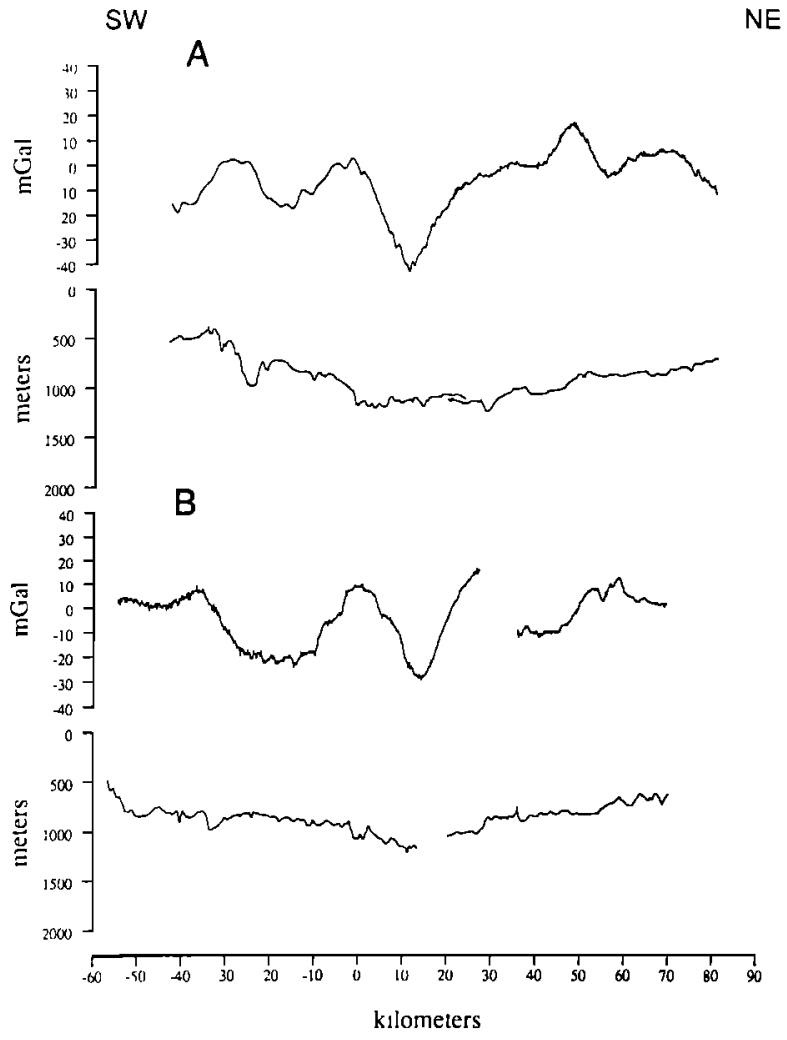

Fig. 9. Free-air gravity anomaly and bathymetry profiles across the center of the Red Sea in areas where the axial depression is less well developed. Profile A is located about $30 \mathrm{~km}$ north and Profile B about $65 \mathrm{~km}$ south of the profile shown in Figure 5 . Locations of the lines are shown in Figure 2. Both profiles are projected along $\mathrm{N} 50^{\circ} \mathrm{E}$.

The depth to Moho is between $13 \mathrm{~km}$ and $14.5 \mathrm{~km}$ for all four of the northern set of lines (Figure 4). A clear refracted mantle arrival with a $P$ wave velocity of $8.2 \mathrm{~km} / \mathrm{s}$ is seen in ESP 3. For the other three lines, the depth to Moho was determined from reflection hyperbolae interpreted as originating from the crust-mantle boundary [Gaulier et al., 1988]. The crustal thickness is between $6.2 \mathrm{~km}$ and $6.8 \mathrm{~km}$ for ESPs 4, 5, and 6 and $8.5 \mathrm{~km}$ for ESP 3, nearest to the coast (Figure 7). Crustal $P$ wave velocities are in the range of 5.8-6.4 km/s except for ESP 3, in which a $2.8 \mathrm{~km}$ thick low-velocity upper crustal layer with a velocity of $5.5-5.7 \mathrm{~km} / \mathrm{s}$ overlies a lower layer with a $6.2 \mathrm{~km} / \mathrm{s}$ velocity (Figure 7).

The southern set of ESPs also show a thin crust $(5-9 \mathrm{~km})$ beneath the Red Sea. However, they gave much higher crustal velocities for ESPs 8-10 (see Figure 4 for location). These velocities are in the range of $6.7-6.8 \mathrm{~km} / \mathrm{s}$ for ESPs 8 and 9, and 6.45$6.7 \mathrm{~km} / \mathrm{s}$ for ESP 10. ESP 11, which is located in the axial depression, gave crustal velocities of 6.3$6.5 \mathrm{~km} / \mathrm{s}$. A $S 45^{\circ} \mathrm{W}$ seismic refraction line passing through the midpoints of ESPs 8-11 also gave a lower-crustal velocity of $6.9 \mathrm{~km} / \mathrm{s}$, in agreement with the ESPs [Avedik et al. 1988]. ESP 7, located about
$15 \mathrm{~km}$ offshore, shows a more complex two layer crust with an upper $6.2-6.45 \mathrm{~km} / \mathrm{s}$ layer overlying a high velocity $7.2 \mathrm{~km} / \mathrm{s}$ lower crustal layer. The total crustal thickness determined for ESP 7 is $9 \mathrm{~km}$.

The reasons for the different crustal velocity structure determined beneath the northern and southern sets of ESPs is the subject of some controversy. Gaulier et al. [1988] and Le Pichon and Gaulier [1988] interpret the difference as resulting from a transition from thin continental crust in the north to Miocene and younger continental crust in the south. Cochran and Martínez [1988], on the other hand, argue that continental crust is present under both regions. They suggest that the difference in the crustal velocities reflects a fundamental difference in the nature of the continental basement which is observed onshore where primarily granitic rocks are found in the North Eastern Desert, while large areas of mafic rocks are found in the Central Eastern Desert [Stern et al., 1984; Stern and Hedge, 1985; Greiling et al., 1988]. The geological and geophysical data necessary to definitively resolve this controversy are not presently available. However, the gravity line which we have chosen for analysis in this study (Figures 4 and 5) is located in the northern region where the marginal areas of the Red Sea are agreed to be underlain by thinned continental crust.

The axial depression appears to be anomalous in both the northern and southern sets of ESPs. In both cases, the ESP over the axial region (ESP 6 and ESP 11) is characterized by distinctly lower velocities than the lines run over the marginal areas (Figure 7). In addition, ESPs 14, 6, and 13, all centered over the axial depression, show very different crustal structures even though their midpoints are spaced only about $10 \mathrm{~km}$ apart (Figure 7). Gaulier et al. [1988] also point out that high crustal velocities were determined for ESP 14 which is centered near Conrad Deep which Cochran et al. [1986] concluded is underlain by a large, shallow intrusion. Gaulier et al. [1988] suggest that these results imply that the crust beneath the axial depression is very complex and heterogeneous, and that it has been both highly fractured and intruded. The fact that the ESPs from the axial region were generally of poorer quality than those in the marginal areas [Gaulier et al., 1988] also suggests a heterogeneous structure.

The midpoint of ESP 3 is located approximately $30 \mathrm{~km}$ offshore (Figure 3). Makris et al. [1982] discussed a seismic refraction experiment along the Egyptian coast between $26^{\circ} 45^{\prime} \mathrm{N}$ and $24^{\circ} 30^{\prime} \mathrm{N}$ which they interpret to show a crustal thickness of about 20 $\mathrm{km}$. They also report an unusually low mantle velocity of $7.5 \mathrm{~km} / \mathrm{s}$ with normal mantle $(8.2 \mathrm{~km} / \mathrm{s})$ found below a depth of about $32 \mathrm{~km}$. Makris et al. [1983] report an almost identical crustal structure for a profile along the Arabian coast between about $26^{\circ} 20^{\prime} \mathrm{N}$ and $24^{\circ} \mathrm{N}$. Makris et al. [1982] and Rihm and Makris [1989] also each presented a seismic refraction profile perpendicular to the rift, at about $26^{\circ} 50^{\prime} \mathrm{N}$ and at about $26^{\circ} \mathrm{N}$ respectively. The shot and receiver geometry for these lines is such that they do not provide information on the crustal structure 
within about $30 \mathrm{~km}$ of the coast. Further inland, both profiles are interpreted as showing a 30 to 32 $\mathrm{km}$ thick continental crust between 30 and $70 \mathrm{~km}$ from the coast. An earlier interpretation of the $26^{\circ} 50^{\prime} \mathrm{N}$ Qena profile [Makris et al., 1982] showed a deepening of the Moho from 30 to $35 \mathrm{~km}$ between 30 and $70 \mathrm{~km}$ from the coast.

The seismic data thus indicate that the northern Red Sea is underlain by thin crust which thickens rapidly near the coast. The crustal thickness increases from $8.5 \mathrm{~km}$ to $20 \mathrm{~km}$ in a distance of about $15 \mathrm{~km}$ between ESP 7 of Gaulier et al. [1988] and the coastal profile of Makris et al. [1982], and all of the crustal thinning associated with the rifting appears to have occurred within $30 \mathrm{~km}$ of the present coastline. These observations agree with the results of the Saudi Arabian seismic refraction profile [Healy et al., 1982], which crosses from the Arabian Shield into the southeastern Red Sea rift near $17^{\circ} \mathrm{N}$. That experiment has been the subject of a number of analyses [e.g., Mooney et al,. 1985; Prodehl, 1985; Milkereit and Flüh, 1985; Mechie et al., 1986] which all agree that the major crustal thinning from about 40 $\mathrm{km}$ beneath Arabia to about $15 \mathrm{~km}$ within the Red Sea rift occurs in a distance of less than a few tens of km near the present coastline.

Heat flow data provide information on both the thermal structure of the mantle beneath the northern Red Sea and the manner in which extension has occurred. Martínez and Cochran [1989] presented three heat flow traverses across the Red Sea with stations spaced approximately $2-3 \mathrm{~km}$ apart. All three profiles show a systematic increase from values of about $125 \mathrm{~mW} / \mathrm{m}^{2}$ seaward of the coasts to values of greater than $250 \mathrm{~mW} / \mathrm{m}^{2}$ associated with the axial depression. Terrestrial heat flow data show a pattern of low to normal heat flow $\left(35-55 \mathrm{~mW} / \mathrm{m}^{2}\right)$ in the interior of Egypt with values increasing to 75-100 $\mathrm{mW} / \mathrm{m}^{2}$ in a band extending about $40 \mathrm{~km}$ from the coast [Morgan et al., 1980, 1985]. The combination of terrestrial and marine measurements thus completely defines the thermal anomaly associated with rifting in the northern Red Sea. The heat flow pattern across the northern Red Sea rift exhibits a fivefold increase from the background level in the stable interior of Egypt [Morgan et al., 1980, 1985].

The large variation in heat flow across the rift along with maximum bounds on the total amount and rate of plate separation thus place strong constraints on the form of lithospheric extension within the rift. A characteristic of all time-dependant numerical models which successfully predict the observed heat flow is that they result in a mantle temperature structure very similar to that of a mid-ocean ridge [Cochran and Martínez, 1988; Le Pichon and Gaulier, 1988]. In addition to a purely oceanic model, a rifting model in which a zone of pure shear extension is initially distributed across the width of the rift and then becomes concentrated toward the center is able to match the overall pattern of heat flow across the rift as well as the peak values in the center, and also to satisfy limiting plate kinematic constraints [Buck et al., 1988; Le Pichon and Gaulier, 1988;
Martínez and Cochran, 1989]. The seismic refraction results demonstrating the presence of thin crust extending seaward from the coastline [Gaulier et al., 1988] also requires that extension occurred over the entire width of the rift through much of its history.

\section{GRAVITY MODELING}

The gravity models were computed using a program based on the line integral method of Talwani et al. [1959]. This is a two-dimensional method and thus assumes that the modeled structure extends indefinitely in both directions from the modeled profile. The profile that we are utilizing for the gravity modeling is located near the center of an approximately $60 \mathrm{~km}$ long segment of the Red Sea in which the structure of the Red Sea is lineated perpendicular to our profile [Martínez and Cochran, 1988]. It thus appears that the assumption of two-dimensionality is fairly reasonable, particularly for the deeper structure.

There is fair control on the sediment and crustal structure for the Egyptian half of our gravity and bathymetry profile. In our calculations, we use values for the density of the sediments which are consistent with well logs obtained in the immediate area of our study [P. Miller, personal communication, 1986]. These are $2000 \mathrm{~kg} / \mathrm{m}^{3}$ for the postevaporite sediments, $2300 \mathrm{~kg} / \mathrm{m}^{3}$ for the Miocene "evaporites" (actually interbedded evaporites and clastics) and $2450 \mathrm{~kg} / \mathrm{m}^{3}$ for the preevaporite sediments. We assume a uniform density for the crust, having no information on the variation of density with depth. The density adopted for the crust is $2790 \mathrm{~kg} / \mathrm{m}^{3}$ at $0^{\circ} \mathrm{C}$, a reasonable average value, as discussed below. For the mantle, we assume a density of $3330 \mathrm{~kg} / \mathrm{m}^{3}$ at $0^{\circ} \mathrm{C}$ which gives a density contrast of $540 \mathrm{~kg} / \mathrm{m}^{3}$ at the Moho.

\section{Shallow Structure}

The observed bathymetry from the profile shown in Figure 5 was used to define the seafloor for the gravity models (Figure 10). The profile terminates only $8 \mathrm{~km}$ off the Egyptian coast in $40 \mathrm{~m}$ of water. However, it ends approximately $35 \mathrm{~km}$ offshore on the Arabian side and the profile was continued to shore in a simple manner consistent with the existing maps. The onshore regions were assumed to be at sea level in the calculations, and this portion of our calculated gravity anomaly profiles should therefore be compared with Bouguer anomalies. However, the mass of the rift shoulders was included in mass balance computations. For this purpose we assumed a $10 \mathrm{~km}$ wide coastal plain, behind which the Red Sea Hills rise to a height of $1000 \mathrm{~m}$ at a distance of $20 \mathrm{~km}$ from the shore. The elevation then falls off to $350 \mathrm{~m}$ at a distance of $120 \mathrm{~km}$ from the shore, and a baseline elevation of $350 \mathrm{~m}$ is assumed in the interior of the continent. This is a reasonable approximation for Egyptian elevations (Figure 8) but is somewhat low for Arabia. However, we have no gravity data along our profile line in Arabia to constrain the calcu- 
lated anomalies, and this assumption thus does not affect our conclusions.

The top and the base of the evaporites were determined for the African side of the profile from Exxon MCS line ERS 74, which coincides with the modeled profile. For the Arabian side, we assumed a constant thickness of $250 \mathrm{~m}$ for the postevaporite sediments toward the center of the sea, thickening toward the coast in a manner similar to what is observed on the African side [Guennoc et al,. 1988, Martínez and Cochran, 1988]. The base of the evaporites on the Arabian side was defined by reflecting a smoothed version of the ERS 74 data about the axis of the sea.
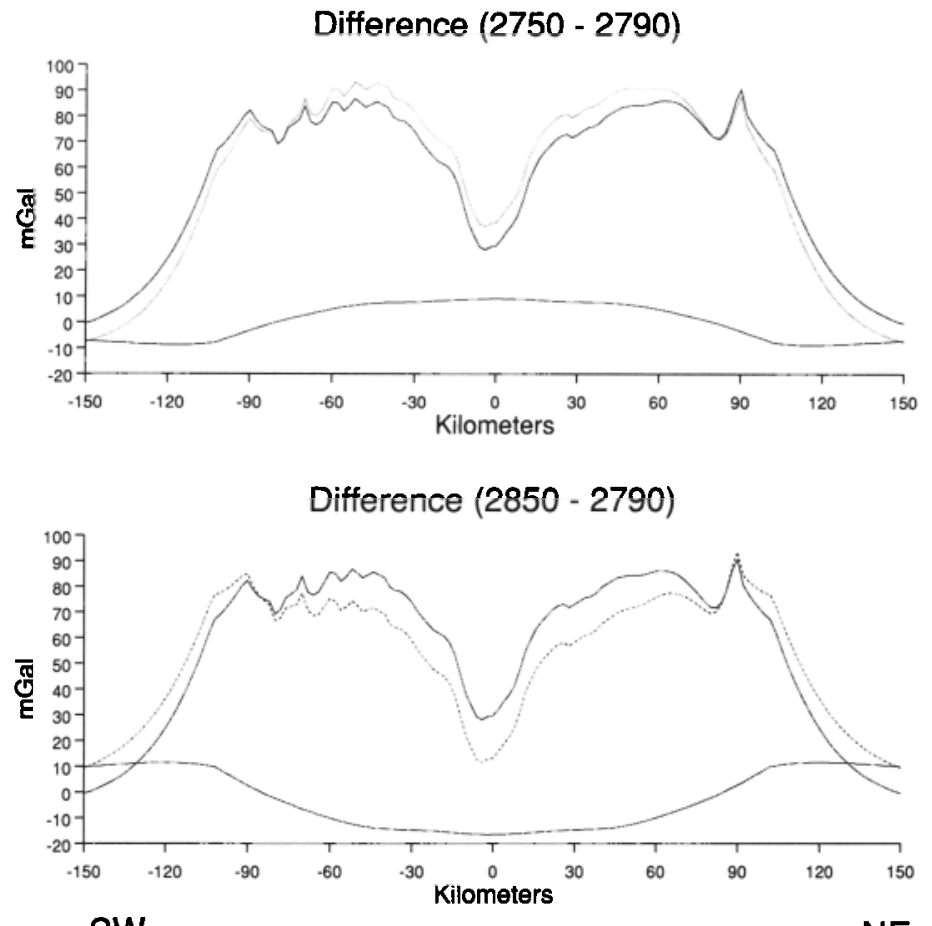

SW

NE

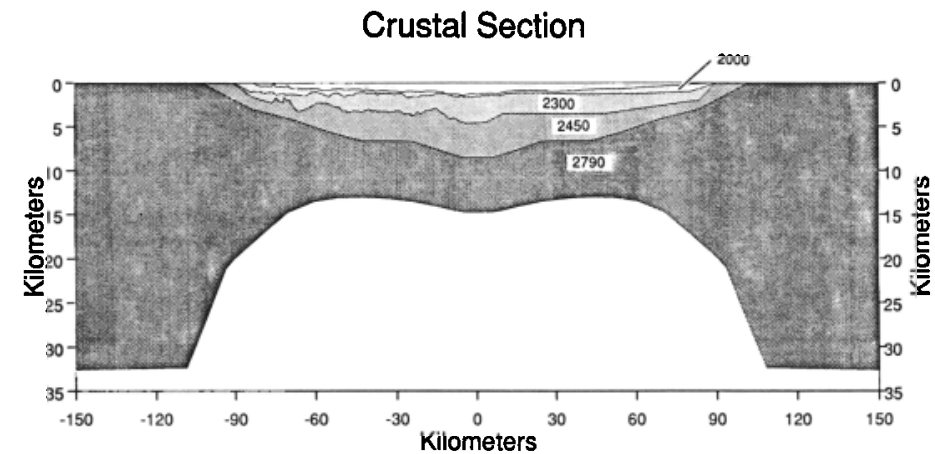

Fig. 10. Gravity effect of variations in average crustal density. The lower panel shows the crustal section across the Red Sea adopted as a starting point for gravity modeling. Depth to basement and crustal thickness on the Egyptian (SW) side of the sea are based on the northern line of Minos ESP experiments (Figure 7a) and on available onshore seismic refraction results [Makris et al., 1982; Rihm and Makris, 1989]. Sediment structure on the Egyptian side is based on digitized reflectors from Exxon seismic line ERS-74 which is coincident with our gravity profile (Figure 5) and is tied to wells in the vicinity [Miller and Barakat, 1988]. Crustal and sediment structure on the Arabian (NE) side of the sea are based on the assumption of symmetry. The upper panels show calculated gravity anomaly profiles demonstrating the effects of varying the crustal density from the value of 2790 $\mathrm{kg} / \mathrm{m}^{3}$ assumed in this study. The top panel shows gravity anomalies calculated for crustal densities of $2790 \mathrm{~kg} / \mathrm{m}^{3}$ (solid curve) and $2750 \mathrm{~kg} / \mathrm{m}^{3}$ (dotted curve) and the middle panel shows anomalies calculated for crustal densities of $2790 \mathrm{~kg} / \mathrm{m}^{3}$ (solid curve) and 2850 $\mathrm{kg} / \mathrm{m}^{3}$ (dashed curve). In each case, the difference between the two calculated profiles is also shown. 


\section{Crustal Structure and Density}

The crustal thickness within the Red Sea is constrained on the African side by ESPs 3-6. We defined an initial crustal structure by smoothly joining the top and base of the crust defined at the four ESPs, with the assumption of symmetry about the axis (Figure 10). The top of the crust was later modified to match the short-wavelength gravity highs and lows. The depth to the top of the crust was kept fixed at the locations of the ESP measurements during this process. The crustal thickness was assumed to be $20 \mathrm{~km}$ at the shoreline in accord with seismic refraction results reported by Makris et al. [1982, 1983], and the continental crust was assumed to have a thickness of $33 \mathrm{~km}$ at distances of more than $20 \mathrm{~km}$ from the coast.

A typical density for the upper crust is 2700 $\mathrm{kg} / \mathrm{m}^{3}$, and a typical lower crustal density is 2900 $\mathrm{kg} / \mathrm{m}^{3}$. The average crustal density will then be somewhere between $2750 \mathrm{~kg} / \mathrm{m}^{3}$ and $2850 \mathrm{~kg} / \mathrm{m}^{3}$, depending on the relative proportions of upper and lower crust. The upper crust in northern Egypt is largely granitic [Stern et al., 1984] and one would thus expect a crustal density in the middle or lower portion of the acceptable range. We arbitrarily adopted a uniform value of $2790 \mathrm{~kg} / \mathrm{m}^{3}$ for the density of the crust. For comparison, the average crustal densities in Egypt in a gravity model shown by Rihm and Makris [1989] range from $2770 \mathrm{~kg} / \mathrm{m}^{3}$ to 2820 $\mathrm{kg} / \mathrm{m}^{3}$.

However, we wish to consider the effect of varying the crustal density, since the crust-mantle and sediment-crust interfaces represent two of the major density contrasts contributing to the gravity anomalies. We do this by examining the effects of changing the crustal density in the range of 2750 to 2850 $\mathrm{kg} / \mathrm{m}^{3}$. Figure 10 compares the gravity effects of sections with average crustal densities of 2750 , 2790 , and $2850 \mathrm{~kg} / \mathrm{m}^{3}$. The mantle density under the unthinned continent is assumed to be $3330 \mathrm{~kg} / \mathrm{m}^{3}$ in all three cases. Under the Red Sea, we assume a constant mantle density for these calculations such that the column at the axis is in local isostatic equilibrium with the column under the adjacent unthinned continent, assuming a compensation depth at the base of the lithosphere $(125 \mathrm{~km})$. The resulting mantle densities are $3279 \mathrm{~kg} / \mathrm{m}^{3}$ for a crustal density of $2750 \mathrm{~kg} / \mathrm{m}^{3}, 3289 \mathrm{~kg} / \mathrm{m}^{3}$ for $2790 \mathrm{~kg} / \mathrm{m}^{3}$, and 3303 $\mathrm{kg} / \mathrm{m}^{3}$ for $2850 \mathrm{~kg} / \mathrm{m}^{3}$.

The difference between the anomalies calculated using the various crustal densities takes the form of a long-wavelength variation (Figure 10) which basically reflects the variation in the crustal thickness across the Red Sea. The major effect of the variations in crustal density is thus a change in the size of the gravity step between the unthinned continent and the Red Sea. The shape and amplitude of the calculated anomalies within the Red Sea is nearly the same for all three cases and our investigation of the structure beneath the Red Sea is not strongly dependent on the exact choice of a density for the crust .

\section{Temperature Variations in the Mantle}

One of the primary features of the gravity calculations shown in Figure 10 is the presence of a 55 mGal gravity minimum over the axis of the Red Sea relative to the marginal areas, which is essentially independent of the crustal density contrast assumed. Since we have assumed a constant mantle density in the models shown in Figure 10, this negative anomaly results from the increase in water depth and sediment thickness toward the center of the Red Sea, which is not balanced by a corresponding decrease in crustal thickness. The observed free-air gravity anomalies also show a minimum over the axis of the Red Sea, but the observed minimum is much narrower than the calculated anomaly and has an amplitude of about $30 \mathrm{mGal}$, or $25 \mathrm{mGal}$ less than that computed from the simple models of Figure 10.

A major problem is then to determine the cause of this $25 \mathrm{mGal}$ discrepancy. Considering the relatively constant crustal thickness determined from seismic experiments in the northern Red Sea [Gaulier et al., 1988], the first obvious explanation would be an increase in the density of the mantle toward the axis. However, the heat flow data [Martínez and Cochran, 1989] show a very marked increase in heat flow toward the axis with the unescapable conclusion that the mantle is hotter and therefore less dense under the axial region.

We now wish to determine the effect on the gravity of the temperature variations in the mantle required by the heat flow measurements. Le Pichon and Gaulier [1988] and Cochran and Martínez [1988] have both pointed out that the heat flow variation away from the axis of the northern Red Sea is not significantly different from the heat flow expected over a mid-ocean ridge extending at the same rate. The dashed curve in Figure 11 shows the results of a simple approximation using a one-dimensional cooling plate model with a total opening velocity of 8 $\mathrm{mm} / \mathrm{yr}$. The solid curve shows the results of a model in which the temperature structure was computed assuming an initial period of extension spread uniformly across the width of the rift for 15.5 m.y., followed by concentrated extension at the axis since 4.5 Ma [Le Pichon and Gaulier, 1988]. This model also incorporates lateral heat conduction. In both calculations we have assumed a linear temperature gradient with depth beneath the unthinned continental crust. The gravity effect of the mantle temperature distribution was calculated by producing a grid of temperature values in the mantle which were converted to density using a coefficient of thermal expansion of $3.4 \times 10^{-5}$. The densities were then contoured at 10 or $20 \mathrm{~kg} / \mathrm{m}^{3}$ intervals to form a series of bodies which were assigned the average density of the contours bounding them.

The two thermal models produce basically the same calculated gravity anomalies. Other published thermal models which match the heat flow [e.g. Buck et al., 1988; Martínez and Cochran, 1989] would not introduce significant variations in the gravity anomalies. Since any model for the devel- 


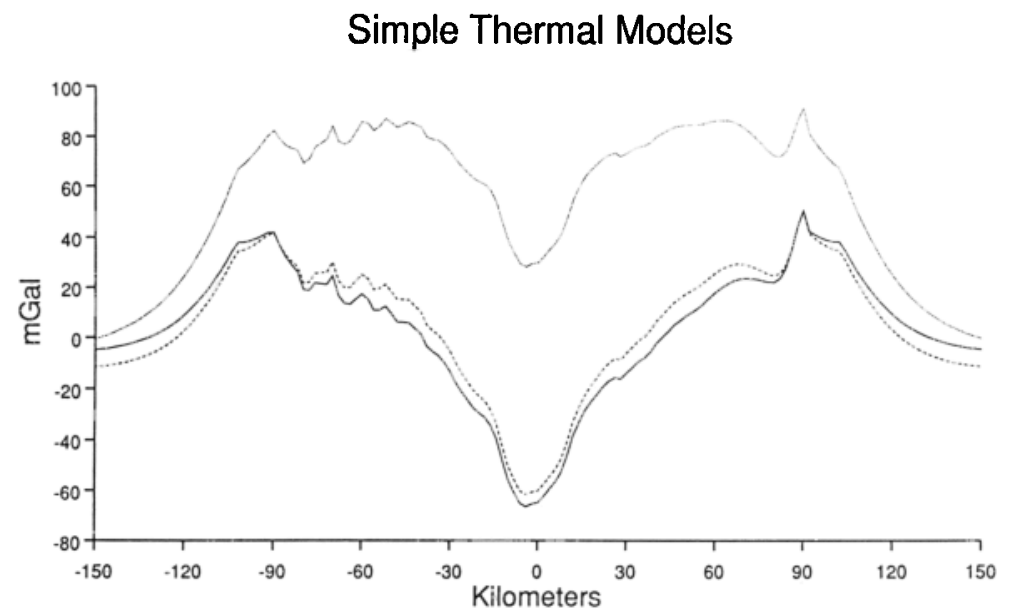

Fig. 11. Calculated gravity anomaly profiles showing the effects of introducing a mantle density structure compatible with heat flow data [Martínez and Cochran, 1989] from the northern Red Sea. The dotted curve shows anomalies calculated assuming a constant density mantle beneath the Red Sea. The dashed curve shows anomalies resulting from the assumption of a mantle density structure calculated from a simple one-dimensional cooling plate model with an opening rate of $8 \mathrm{~mm} / \mathrm{yr}$. The solid curve shows anomalies resulting from a thermal model in which extension is assumed to be uniformly distributed across the rift for 15.5 m.y. followed by concentrated extension at the axis for 4.5 m.y. [Le Pichon and Gaulier, 1988]. Other thermal models [Buck et al., 1988; Martínez and Cochran, 1989] which match the heat flow data result in gravity anomalies that do not differ significantly from these two profiles.
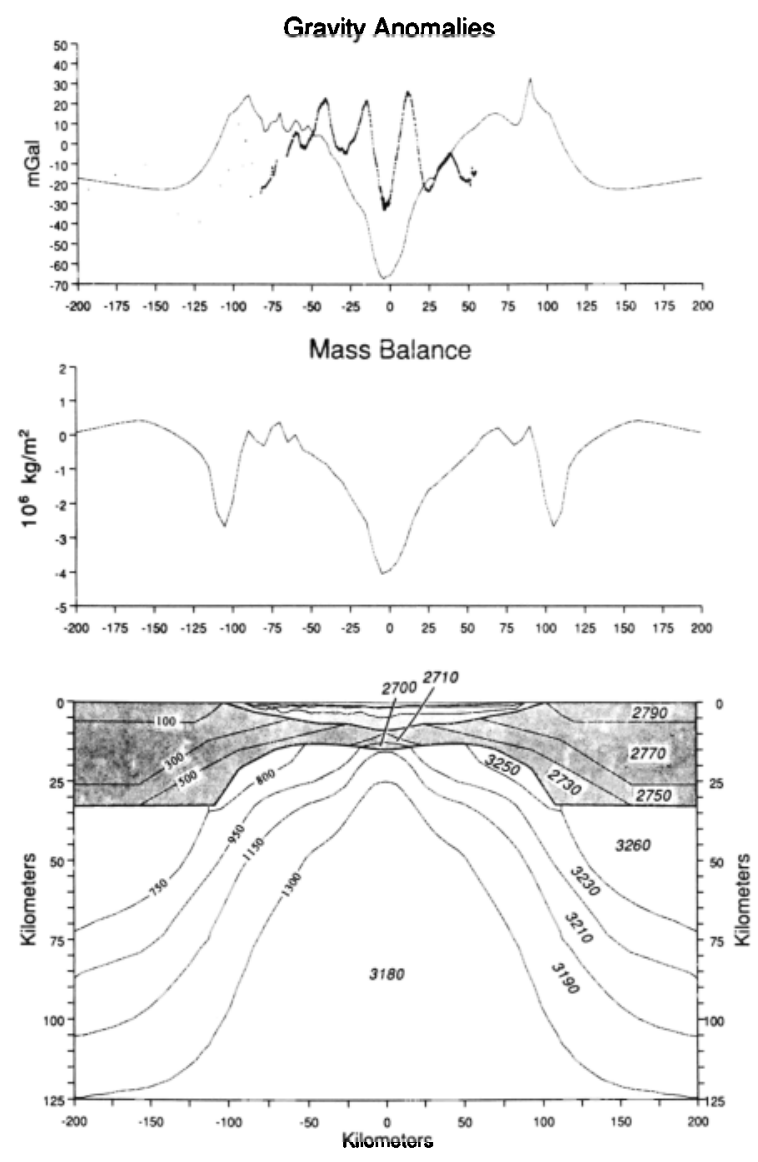

opment of the Red Sea which satisfies the heat flow data results in a thermal structure similar to those of the models shown in Figure 11, we will arbitrarily adopt the mantle thermal structure of the Le Pichon and Gaulier [1988] model (Figure 11, solid line) for all subsequent gravity models. In addition, we will extend the temperature structure resulting from the model under the subcontinental mantle and within the crust to take into account conductive effects. Figure 12 shows the resulting thermal and density structure for the profile and compares the calculated gravity anomalies with the observed data.

The main result from the model calculations shown in Figures 11 and 12 is that, independent of

Fig. 12. Gravity effect of introducing a mantle and crustal thermal structure compatible with geothermal measurements. The bottom panel shows isotherms calculated using the kinematic model of Le Pichon and Gaulier [1988]. Isotherms are labeled with temperature in degrees Celsius. Bodies defined by the isotherms are labeled with the density in kilograms per cubic meter assigned to each body. Gravity anomalies calculated from this model (solid curve) and observed gravity anomaly values (dots) are shown in the top panel Note disagreement between observed and calculated anomalies. Middle panel shows mass balance curve across the Red Sea for the model shown. The mass of a lithospheric column away from the Red Sea within the undisturbed continent was taken as a reference. 
the details of the opening history, introducing a thermal structure in the mantle which is compatible with heat flow data serves to increase the calculated gravity minimum beneath the axial region by $25-30$ $\mathrm{mGal}$, so that it has an amplitude of about $75 \mathrm{mGal}$. There is thus a $\mathbf{4 0} \mathrm{mGal}$ discrepancy between models and observations. The introduction of the thermal density variations in the mantle has also broadened the calculated gravity low over the Red Sea so that it takes the form of a gradient down from the margins to the axis.

This discrepancy is also evident in the mass balance across the section. Figure 12 also shows profiles of the variation of mass in vertical columns across the model. The mass of a continental section away from the influence of the Red Sea is used as a standard reference section. The section at the axis of the Red Sea shows a deficiency of $4 \times 10^{6} \mathrm{~kg} / \mathrm{m}^{2}$ relative to the marginal areas. This is equivalent to the mass of a $4 \mathrm{~km}$ high column of water and is much greater than the uncertainty in any of the known structures included in the gravity model. The sharp mass deficit just landward of each coastline results from our assumption of a $10 \mathrm{~km}$ wide coastal plain in which the rapidly changing crustal thickness is not balanced by a change of elevation. It is equivalent to the mass of the $1 \mathrm{~km}$ of crustal material which was assumed to have been eroded as the escarpment retreated.

\section{Gravity Effects of Local Topography}

Figure 13 shows the effect on the calculated gravity anomalies of modifying the upper surface of the crust to match the short wavelength variations in the observed gravity for each of the models discussed
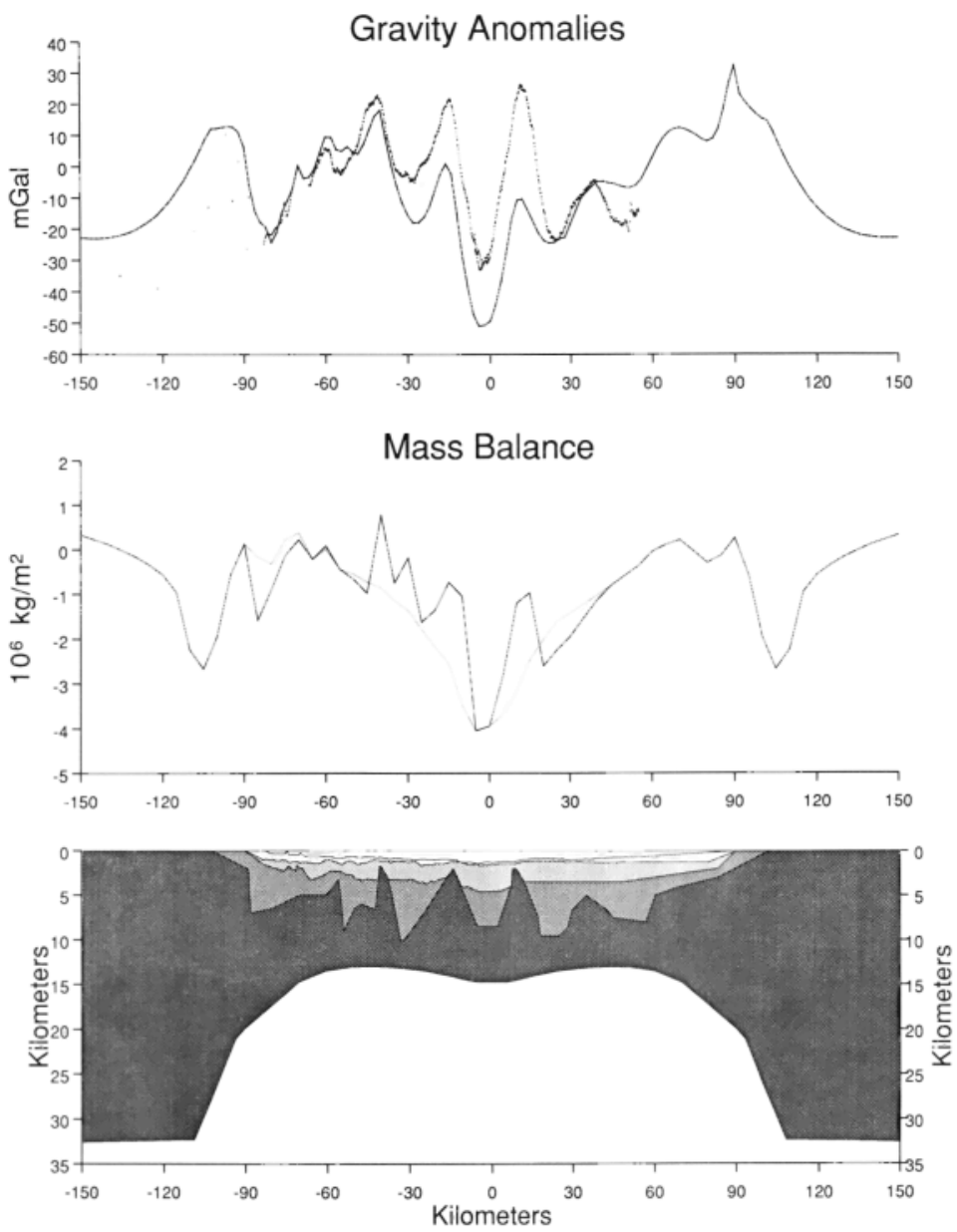

Fig. 13a. Gravity effect of varying the upper surface of the crust in the models to match the short-wavelength variations in the observed anomalies. Crustal structure shown in the lower panel is that used in the "underplating" model (Figure 14). Gravity anomalies calculated using the density structure shown in Figure 12 and this relief on the top of the crust are shown as a solid curve in the top panel. The observed gravity values are shown as dots. The middle panel shows a mass balance curve across the Red Sea for this model. The solid curve shows the mass balance for this model and the dashed curve the mass balance for the thermal model (Figure 12). The mass of a lithospheric column away from the Red Sea within the undisturbed continent was taken as a reference. 
below. The final modification of the shape of the top of the crust was actually done as part of the modeling discussed below. However, we introduce its gravity effect at this point in order to clearly separate the effects of each step in our analysis.

The local gravity highs and lows with amplitudes of 10-40 mGal and widths of about $20 \mathrm{~km}$ were modeled as resulting from relief on crustal fault blocks, following the interpretation of Martínez and Cochran [1988]. The depth to the top of the crust was kept fixed at the locations of the ESP measurements during the modeling. The much simpler crustal structure on the Arabian side of the Red Sea is due simply to the fact that we lack gravity data closer than about $30 \mathrm{~km}$ to the Arabian coast. The greatest relief required on the fault blocks was about $8 \mathrm{~km}$, which is somewhat greater than the maximum relief of about $6 \mathrm{~km}$ observed on blocks in the Gulf of Suez [Colletta et al., 1988; Patton et al., 1991]. The Gulf of Suez was the northern continuation of the Red Sea rift until it was cut off by initiation of the Dead Sea transform in the mid-Miocene [Berthelot, 1986; Steckler and ten Brink, 1986; Courtillot et al., 1987], at which time extension in the Gulf of Suez essentially ceased [Steckler et al., 1988]. Over 100 additional kilometers of extension has occurred in the Red Sea. We therefore believe that this relief on the top of the crust is reasonable.

The least reasonable feature of the crustal sections shown in Figure 13 is the narrow topographic high approximately between kilometers -35 and -42 on both sections. This is not the shape that one would expect from a rotated fault block. The gravity effect of this body also does not completely match the ob-
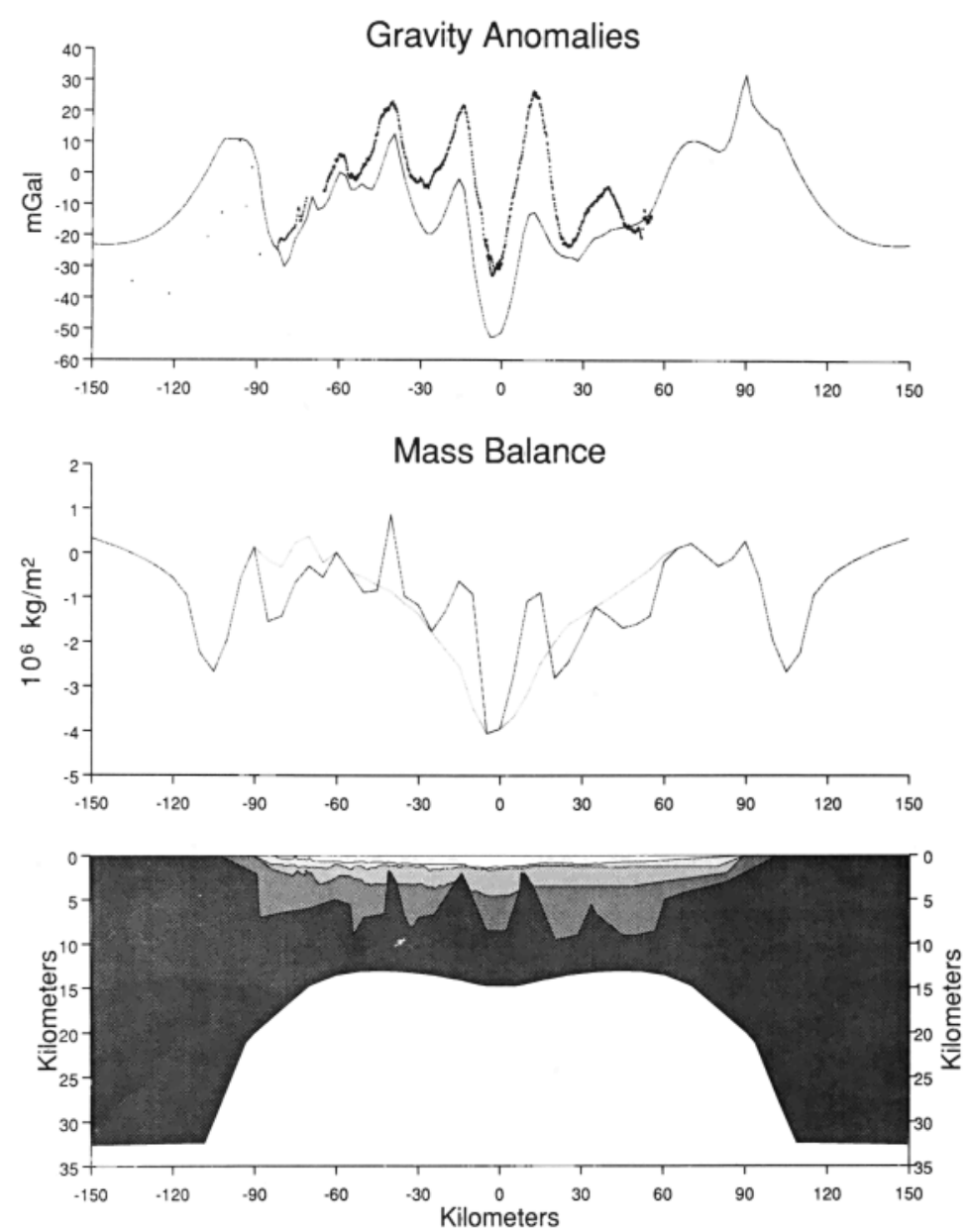

Fig. 13b. Gravity effect of varying the upper surface of the crust in the models to match the short-wavelength variations in the observed anomalies. Crustal structure shown in the lower panel is that used in the "dense axis" model (Figure 15). Gravity anomalies calculated using the density structure shown in Figure 12 and this relief on the top of the crust are shown as a solid curve in the top panel. The observed gravity values are shown as dots. The middle panel shows a mass balance curve across the Red Sea for this model. The solid curve shows the mass balance for this model and the dashed curve the mass balance for the thermal model (Figure 12). The mass of a lithospheric column away from the Red Sea within the undisturbed continent was taken as a reference. 
served data which suggest that the basement high should be somewhat wider. The shape of the model basement is constrained by the requirement that we match the observed depth to basement of $6.6 \mathrm{~km}$ at ESP 4 which has a projected location of $-42.6 \mathrm{~km}$ on our profile. However, ESP 4 is actually centered about $7.5 \mathrm{~km}$ south of the gravity line at a location where the gravity is about $8 \mathrm{mGal}$ less that at the projected location along the gravity line (Figure 4). If we allowed ourselves the freedom to make the depth to basement slightly less at the location of ESP 4 on the gravity line, we could better fit the gravity observations with a wider, lower, more realistic basement relief.

We left the Moho as a smooth surface on the basis of the nearly constant depth to Moho on all of the ESPs within the northern Red Sea. The crust beneath the northern Red Sea thus consists of a broad area of very thin $(\sim 8 \mathrm{~km})$ crust with a smoothly varying Moho, which does not reflect the large relief of the overlying tilted fault blocks. This type of crustal structure has been observed at a number of rifted continental margins where the rifting has not been accompanied by extensive magmatism. Examples include the Bay of Biscay margin [Avedik et al., 1982; Le Pichon and Barbier, 1987; Pinet et al,. 1987], the Goban Spur-Flemish Cap margin [Keen et al., 1989] and the Mediterranean margin of France [Burrus, 1989]. Le Pichon and ChamotRooke [1991] argue that this geometry results from the presence of a brittle upper crustal layer over a ductilely deforming lower crust. They conclude that if the brittle layer maintains even a small effective elastic thickness and if crustal density increases downward, then the large rotated fault blocks can be isostatically supported within the crust by a combination of the elastic strength of the upper crust and ductile flow of the lower crust.

We found no need for the somewhat exotic crustal structure proposed by Rihm and Makris [1989] to explain the local gravity anomalies on a gravity profile across the northern Red Sea which appears to be nearly coincident with ours. Their model shows variations of more than $10 \mathrm{~km}$ in the depth to the mantle over very short horizontal distances (less than $15 \mathrm{~km}$ ) with the result that the crust completely disappears in places. This unlikely crustal structure appears to result from an assumption that the local gravity anomalies result primarily from relief on the crust-mantle boundary, combined with the very small density contrast $\left(220 \mathrm{~kg} / \mathrm{m}^{3}\right)$ which they assumed at that boundary.

The introduction of topography on the top of the crust to match the local gravity anomalies not only introduces short-wavelength variations into the calculated gravity anomalies, but also serves to reduce the amplitude of the calculated gravity low over the axis (Figure 13). This results from the fact that, in order to match the large gravity highs flanking the axial depression on the profile which we are modeling (Figures 4 and 5), we had to introduce large tilted fault blocks which significantly increased the mass at shallow depth near the axis. However, although this reduces the gravity low at the axis relative to the marginal areas from about $75 \mathrm{mGal}$ to about 55 $\mathrm{mGal}$, it is still significantly greater than the observed $30 \mathrm{mGal}$ low.

The mass balance profile is also affected by the introduction of relief on the top of the crust. The introduction of sizable blocks and basins results in the creation of local variations in mass with the same width as the blocks. These are characteristically less than $20 \mathrm{~km}$ across and we assume that the stresses implied by these mass variations are supported by the strength of the lithosphere [Le Pichon and ChamotRooke, 1991]. The long-wavelength pattern showing a mass imbalance between the axis and the marginal areas is not affected by the introduction of the crustal topography.

\section{Two possible Solutions}

We concluded in the previous section that the knowledge that we have of the structure of the crust and mantle beneath the Red Sea leads to a $25 \mathrm{mGal}$ discrepancy between models and observations. The computed model is relatively too dense under the marginal areas of the sea compared to the axis. There are two possible solutions; either add mass to the axial zone or decrease the mass under the marginal area.

Given the available geophysical control, the only reasonable geologic mechanism apparent to us that would add negative mass under the marginal regions of the northern Red Sea is crustal underplating. Crustal underplating has been inferred to have occurred at a number of rifted margins on the basis of intermediate $(7.2-7.6 \mathrm{~km} / \mathrm{s}) \mathrm{P}$ wave velocities observed in the lower crust at a number of continental rifts and rifted continental margins [e.g., LASE Study Group, 1987]. Gaulier et al. [1988] did not obtain mantle velocities at ESPs 4, 5, and 6 along our gravity profile, and the base of the crust is determined from reflection hyperbolae for those ESPs. A well determined $8.2 \mathrm{~km} / \mathrm{s}$ mantle velocity at a depth of $13.4 \mathrm{~km}$ with no intermediate velocity layer was determined at the westernmost profile, ESP 3. Although this latter ESP, nearest the coast, does not fit with an underplating model, the other three ESPs, where the base of the crust is defined by a reflection, are not inconsistent with the presence of such a deeper crustal layer. In addition, lower crustal layers with velocities between $7.2 \mathrm{~km} / \mathrm{s}$ and $7.7 \mathrm{~km} / \mathrm{s}$ were observed on ESPs 7, 9, and 10 on the southern line of ESPs, although, as discussed earlier, the entire velocity structure of the southern set of ESPs differs from that of the northern set.

The gravity anomalies resulting from a model in which a lower "underplated" crustal layer with a $0^{\circ} \mathrm{C}$ density of $3000 \mathrm{~kg} / \mathrm{m}^{3}$ is included under the marginal areas is shown in Figure 14. The deep crustal layer is modeled as extending from the coast to a distance of $24.3 \mathrm{~km}$ from the axis (the location of ESP 5) and has a maximum thickness of $5 \mathrm{~km}$ at $60.5 \mathrm{~km}$ from the axis (the location of ESP 3). The replacement of mantle with the lower-density material reduces the 

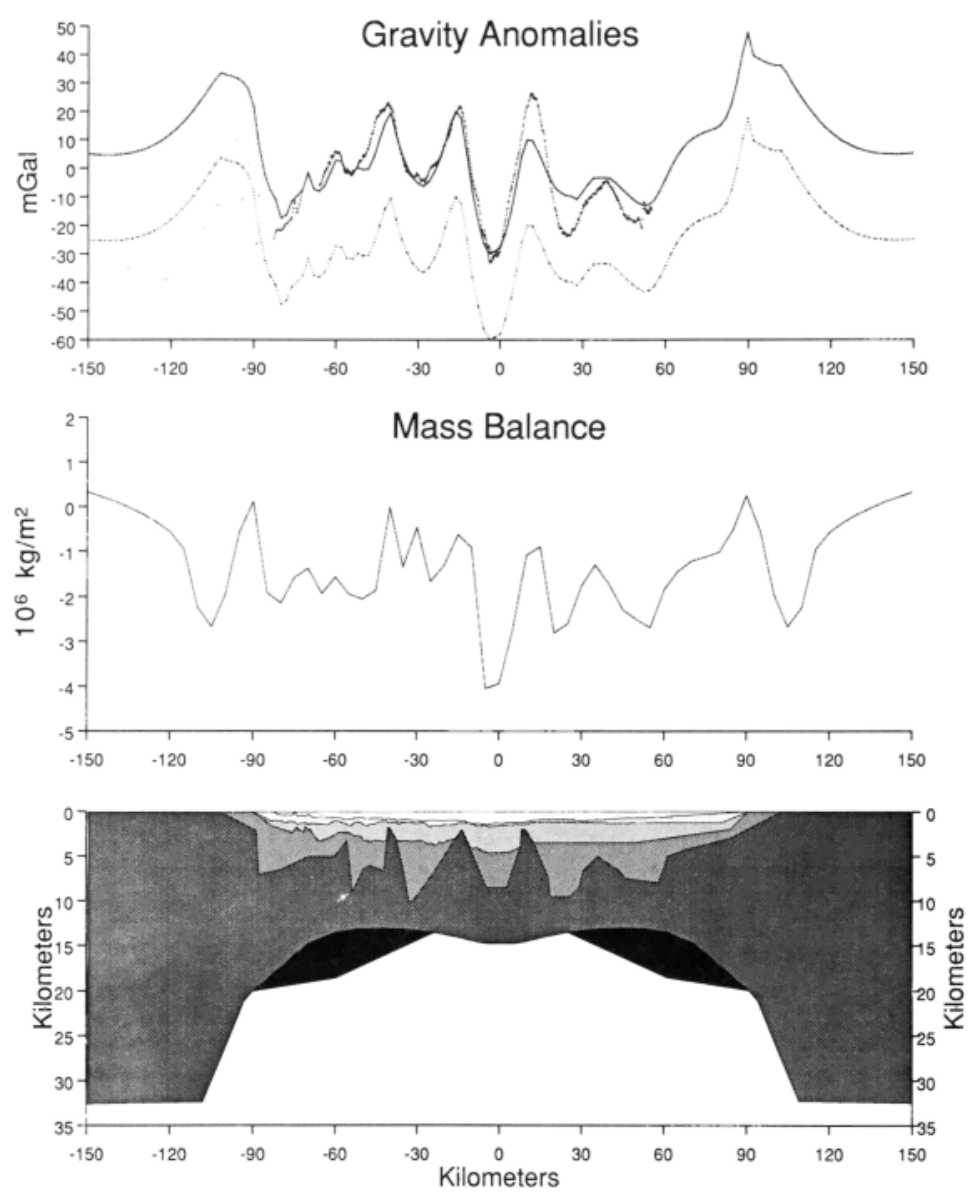

Fig. 14. Gravity effect of introducing a lower "underplated" crustal layer beneath the marginal areas of the Red Sea. The density of the darkly shaded area in the lower panel was reduced by $330 \mathrm{~kg} / \mathrm{m}^{3}$ so that a $0^{\circ} \mathrm{C}$ density of $3000 \mathrm{~km} / \mathrm{m}^{3}$ is assumed for the underplated layer. Other densities are as shown in Figure 12 . Observed gravity anomalies (dots) and calculated anomalies resulting from this model are shown in the upper panel. The dashed curve shows the calculated anomalies, and the solid curve the calculated anomalies with a constant $30 \mathrm{mGal}$ shift applied to bring the general level of the anomalies up to that of the observed data. The mass balance for this model is shown in the middle panel. The mass of a lithospheric column away from the Red Sea within the undisturbed continent was taken as a reference.

total mass and results in a general level of about -30 $\mathrm{mGal}$ for the calculated gravity anomalies over the Red Sea (Figure 14, dashed line). We therefore arbitrarily added a constant $30 \mathrm{mGal}$ to the calculated profile so that its level corresponds to the level of the observed anomalies (Figure 14, solid line). The introduction of the deep crustal layers removes the 25 mGal discrepancy between the axis and the marginal areas. The resulting calculated gravity anomalies adequately match the observed anomalies within the Red Sea, although we were not able to completely reproduce the short-wavelength anomalies on the Arabian side of the axis.

The alternative to decreasing the mass in the marginal areas is to increase the mass near the axis. Figure 15 shows the gravity anomalies resulting from a model in which this is accomplished by assuming that the average density of the crust is in- creased by $110 \mathrm{~kg} / \mathrm{m}^{3}$ to $2900 \mathrm{~kg} / \mathrm{m}^{3}$ near the axis. The obvious cause of such an increase in density is large scale igneous intrusions. The geometry of the denser region in Figure 15 is designed to take into account magnetic data which suggest that very large intrusions to shallow depths have occurred along the faults bounding the axial depression at the site of our gravity line [Cochran et al., 1986]. The intruded area is $23 \mathrm{~km}$ wide at the top of the crust and 34.6 $\mathrm{km}$ wide at its base. The calculated gravity anomalies again match the observed anomalies on our profile across the Red Sea.

The introduction of either a deep "underplated" crustal layer in the marginal regions or a denser "intruded" region at the axis not only results in matching the observed gravity anomalies, but also serves to remove the mass imbalance between the marginal areas and the axis of the Red Sea (Figures 

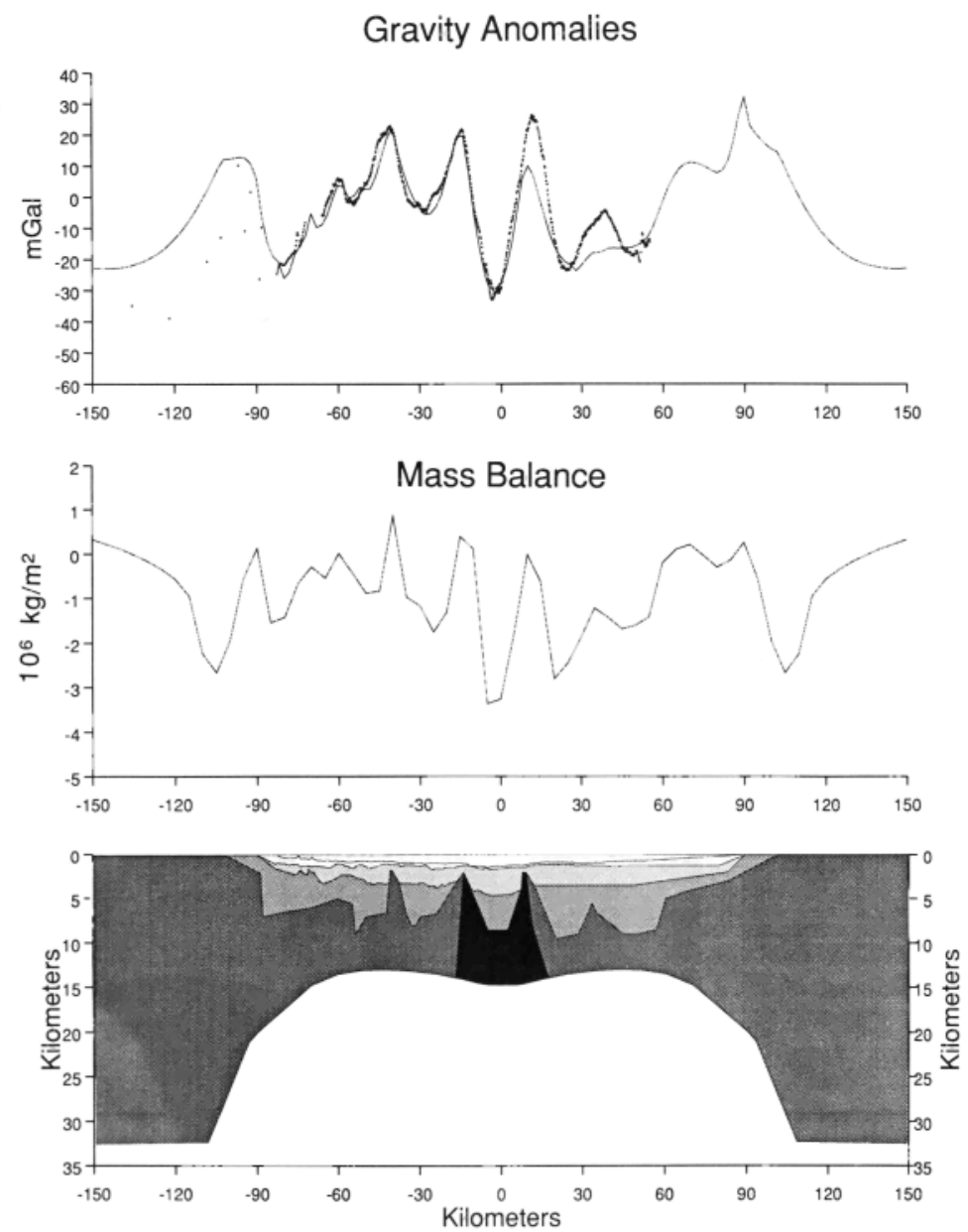

Fig. 15. Gravity effect of introducing a region of increased crustal density beneath the axial depression. The density of the darkly shaded area beneath the axis is assumed to be increased by $110 \mathrm{~kg} / \mathrm{m}^{3}$ so that it has a $0^{\circ} \mathrm{C}$ density of $2900 \mathrm{~km} / \mathrm{m}^{3}$. Other densities are as shown in Figure 12. Observed gravity anomalies (dots) and calculated anomalies (solid curve) resulting from this model are shown in the upper panel. The mass balance for this model is shown in the middle panel. The mass of a lithospheric column away from the Red Sea within the undisturbed continent was taken as a reference.

14 and 15). Although both models still show a large, local mass deficiency at the axis, the general level of mass balance curves is constant across the Red Sea. The level is, however, still negative for both models. For the region between the shorelines, the average mass in a vertical column, relative to the reference section, is $-1.621 \times 10^{6} \mathrm{~kg} / \mathrm{m}^{2}$ for the underplating model (Figure 14) and $-0.918 \times 10^{6}$ $\mathrm{kg} / \mathrm{m}^{2}$ for the intrusion model (Figure 15). These mass deficiencies are equivalent to an increase in the crustal thickness of the reference section of $3.0 \mathrm{~km}$ for the underplating model and of $1.7 \mathrm{~km}$ for the intrusion model.

\section{DISCUSSION}

Both of the models discussed above satisfactorily fit the gravity anomalies within the Red Sea. The extent to which one solution is preferable to the other must therefore depend on the extent to which it is compatible with the entire suite of geophysical data.

The model which assumes underplating in the marginal areas is suggested by the presence of a deep crustal layer with a $\mathrm{P}$ wave velocity in the neighborhood of $7.2 \mathrm{~km} / \mathrm{s}$ at a number of different continental margins [e.g. Diebold et al., 1988; Weigel et al., 1982; Talwani et al., 1979; Keen et al., 1975]. This crustal layer is frequently interpreted as mafic material generated by partial melting of the mantle during rifting. Mantle refractions were not recorded on ESPs 4, 5, and 6. The wide-angle reflection taken as marking the base of the crust on those ESPs [Gaulier et al., 1988] could just as easily come from the upper surface of a high-velocity lower crustal layer. However, ESP 3 gave a very well defined mantle arrival with a velocity of $8.2 \mathrm{~km} / \mathrm{s}$ and no evidence of a high velocity lower crustal layer. This presents a great difficulty for the model of crustal 
underplating, since the additional lower crustal layer in the gravity model is thickest at the location of ESP 3 (km -60.5 on the figures) (Figure 14).

Another difficulty with the model of large-scale underplating of the crust in the marginal regions arises from the fact that this model reduces the total mass under the Red Sea and, as a result, produces gravity anomalies that are in the range of $-30 \mathrm{mGal}$. We dealt with this in Figure 14 by shifting the level of the anomalies by $30 \mathrm{mGal}$ so that the general level of the calculated anomalies matches that of the observed gravity. We are free to do this because the long-wavelength variations of the gravity field, which define the local "regional field" level, arise from deeper sources than those considered here. However, this shift results in slightly positive calculated Bouguer anomalies of 5-10 mGal in eastern Egypt. The alternative model with a denser crust near the center of the Red Sea results in calculated Bouguer anomalies of -20 to $-25 \mathrm{mGal}$ in eastern Egypt (Figure 15). The admittedly somewhat sparse gravity data from Egypt available to us shows generally negative Bouguer anomalies. In particular, a set of gravity measurements along the road from Safaga to Qena, nearly in line with our geophysical profile in the Red Sea, shows Bouguer anomalies in the range of about -15 to $-40 \mathrm{mGal}$ (Figure 8).

The approximately $40 \mathrm{mGal}$ discrepancy between the observed Bouguer gravity anomalies in Egypt and those calculated from the model with crustal underplating could be hypothesized to result from an incorrect crustal density or continental crustal thickness in our calculations. As shown in Figure 10, a change in crustal density is expressed in the gravity as a shift in the level of calculated anomalies between the Red Sea and the interior of the continents. However, to account for the $40 \mathrm{mGal}$ shift, the average density for the entire continental crust would have to be about $2650 \mathrm{~kg} / \mathrm{m}^{3}$, which appears to be unreasonably low. The level of the the gravity anomalies calculated over the continent relative to those over the Red Sea could also be made compatible with the underplating model if the continental crustal thickness used in the modeling is too low. A thicker crust beneath eastern Egypt, in the range of $35-40 \mathrm{~km}$, would remove the discrepancy. This is a reasonable value for continental crustal thickness but is greater than that resulting from available analyses of seismic data [Makris et al., 1982; Rihm and Makris, 1989].

The second model satisfying the gravity data is one in which the density of the crust underlying the axial depression is increased, presumably by largescale intrusion of mafic crustal material in that region. This model is suggested by the association of large magnetic anomalies with the deeps within the axial depression. These magnetic anomalies, which are all dipolar in form, have been interpreted as resulting from large, normally magnetized intrusions [Pautot et al., 1984, 1986; Cochran et al., 1986]. In addition, Pautot et al. [1984] and Altherr et al. [1988] report the recovery of basalt from what appears to be a volcanic peak within Shaban Deep.
Altherr et al. [1988] indicate that this basalt is tholeiitic, with T-type MORB characteristics.

The heat flow data from the northern Red Sea also suggest that partial melting of mantle material should be occurring beneath the axial depression. All three heat flow profiles across the northern Red Sea reported by Martínez and Cochran [1989] show a marked increase from the marginal areas to maximum values over the axial depression. Le Pichon and Gaulier [1988] pointed out that the heat flow across the axis of the Red Sea is very similar to that expected for a mid-ocean ridge [Parsons and Sclater, 1977]. As a result, all models of the temperature structure beneath the northern Red Sea which satisfy the heat flow data require a concentration of high mantle temperatures near the axis. Buck et al. [1988] and Martínez and Cochran [1989] calculated where and when partial melt would be generated for specific extension histories which are compatible with the heat flow data. They found that significant partial melt could be generated near the end of the extension history (i.e. recently), but only within a region less than $50 \mathrm{~km}$ wide centered at the axis. Recently, J.-P. Montagner and T. Tanimoto [personal communication, 1990] have shown from seismic tomography studies that the seismic velocities are anomalously low under the northern Red Sea at depths between 60 and $120 \mathrm{~km}$ which also suggests partial melting there.

The major argument against this solution is that the ESPs within the axial depression do not exhibit crustal $P$ wave velocities that might be expected from a region of dense mafic crust. In fact, for both the northern and southern set of ESPs, the crustal velocities determined within the axial depression are less than those obtained in the marginal areas (See Figure 7). Only ESP 14 , which is located directly over one of the dipolar magnetic anomalies associated with Conrad Deep, gives crustal velocities typical of dense gabbroic rocks. Gaulier et al. [1988] suggest that the lower seismic velocities within the axial depression might be due to a highly fractured and newly intruded crust. They also point out that ESPs 14, 6, and 13, all centered over the axial depression, show very different crustal structures even though their midpoints are spaced only about $10 \mathrm{~km}$ apart (Figure 7), suggesting the presence of a complex, heterogeneous crust beneath the axial depression. Seismic reflection profiles show that the sediments in the axial depression are much more intensely faulted and disturbed than those in the axial regions [Martínez and Cochran, 1988].

There are thus arguments that can be advanced in favor of and in opposition to each of the two models presented here. However, the heat flow data and the samples of tholeiitic basalt in Shaban deep lead us to conclude that partial melting is occurring in the mantle beneath the axial region of the northern Red Sea and that this process has apparently resulted in the emplacement of denser mafic intrusions into the crust of the axial depression.

We cannot discount the possibility that some portion of the magma forms an "underplated" lower 
crustal layer rather than being intruded into and through the crust. However, any underplating is limited to the central half of the Red Sea by the geothermal data, which imply that partial melting must have begun recently and is only possible near the axis [Buck et al., 1988], and by the observation that ESP 3 yielded a normal mantle velocity with no evidence of a high-velocity lower crustal layer. This mechanism (crustal underplating) cannot therefore resolve the problem of the mass imbalance between the marginal and axial regions from the known crustal structure (Figure 12), and it appears that a region of slightly higher (by $\sim 110 \mathrm{~km} / \mathrm{cm}^{3}$ ) density crust must exist beneath the axial depression.

Our geophysical profile (Figure 5) passes through Conrad Deep, which is known to be the site of two large shallow intrusions located along the faults bounding the axial depression [Cochran et al., 1986]. These shallow intrusions are represented in Figure 15 by the shallow areas of the crustal blocks bounding the axial depression that are included in the region of increased density. Away from the deep, where the axial depression is gentler and not fault bounded, the mass of the large crustal blocks and of the shallow intrusions emplaced along them is presumably smaller. However, the depth to the 5.8 $\mathrm{km} / \mathrm{s}$ layer within the axial depression decreases away from the deeps (compare ESPs 13 and 15 with ESP 6 in Figure 7) and thus less excess mass is required beneath the axis away from Conrad Deep to satisfy the gravity data.

We do not have sufficient data available for regions away from Conrad Deep to constrain a detailed gravity model similar to that which we have constructed along the line shown in Figure 5. Rough calculations suggest that, although less additional mass may be necessary, a region of slightly higher density crust about $25 \mathrm{~km}$ wide is still necessary beneath the axial depression to satisfy the observed gravity anomalies. However, we simply do not have sufficient control to adequately constrain the amount of excess mass required.

The gravity data do not directly yield the extent to which the crust of the axial depression is made up of recently intruded material. However, it must be sufficient to raise the average crustal density by 110 $\mathrm{kg} / \mathrm{m}^{3}$ on the line that we modeled, and it is therefore a significant portion of the crust. The gravity modeling also does not constrain the mechanism by which this material was emplaced or the time over which it has been emplaced. Thus whether the crust beneath the axial depression is "oceanic" becomes to some extent a matter of definition. However, our gravity modeling, along with the high heat flow over the center of the Red Sea and the large, normally magnetized intrusions associated with the axial deeps, implies that intrusion of new crustal material is now an important and perhaps the dominant mechanism of extension within the rift.

\section{SUMMARY}

We have used gravity data to investigate the structure of the northernmost Red Sea. Constraints on the the gravity modeling include single-channel and multichannel seismic reflection lines [Martínez and Cochran, 1988; Miller and Barakat, 1988] coincident with our gravity and bathymetry profile which provide detailed information on the thick sedimentary column, a series of expanding spread profiles [Gaulier et al., 1988] centered nearly over our gravity line which provide information on the depth to basement, depth to Moho, and crustal structure within the Red Sea, a series of closely spaced heat flow measurements [Martínez and Cochran, 1989] across the Red Sea nearly coincident with our gravity line which provides information on the mantle thermal structure and thus density variations within the mantle, and seismic refraction experiments onshore in Egypt [Makris et al., 1982] which provide information on the continental crustal thickness.

When all of the available data on the structure of the crust and lithosphere are included in the model, the calculated gravity anomalies fail to match the observed data. The calculated anomalies are approximately $25 \mathrm{mGal}$ more negative at the axis relative to the marginal areas than are the observed gravity anomalies. We investigated two possible solutions to this discrepancy. The first is to introduce a lower crustal layer within what was originally assumed to be the uppermost mantle. This crustal layer with a density of $3000 \mathrm{~kg} / \mathrm{m}^{3}$ is assumed to arise from crustal "underplating" resulting from partial melting within the mantle. The second is to assume slightly denser (by $110 \mathrm{~kg} / \mathrm{m}^{3}$ ) crust within the axial depression in the center of the sea. This region of denser crust is assumed to result from intrusion of new mafic crustal material into the axial depression. Both solutions can reproduce the observed free-air gravity anomalies within the Red Sea. However, when models satisfying the gravity data are considered in light of all of the geophysical data, the most satisfactory solution is that the crust of the axial depression is denser than that of the marginal regions. This implies that crustal extension in the northernmost Red Sea is presently occurring in large part through intrusion of new mafic crustal material.

Acknowledgements. This work has been supported by the U.S. National Science Foundation (grants OCE 87-16701 and OCE 89-18685), Ecole Normale Supérieure, Collège de France, C.N.R.S., INSU, and IFREMER. We thank Esso Exploration Company, and in particular P. Miller and H. Barakat for making available data from their survey of the Safaga Concession. The manuscript was reviewed by Michael Steckler, Walter Smith, Debbie Hutchinson and Bob Bohannon. LDGO contribution 4780 . 


\section{REFERENCES}

Alther, R., F. Henjes-Kust, H. Puchelt, and A. Baumann, Volcanic activity in the Red Sea axial trough, evidence for a large mantle diapir? Tectonophysics, 150, 121-133, 1988.

Tectonophysics, 1so, 121-133, 1988. Montadert, D.G. Roberts, and R.B. Whitmarsh, A seismic refraction and reflection study of the continent - ocean transition beneath the North Biscay Margin, in The Evolution of Sedimentary Basins, edited by P. Kent, M H.P. Bott, D.P. McKenzie, and C.A. Williams, pp. 27-44, The Royal Society, London, 1982.

Avedik, F., L. Gel1, J.-M. Gaulier, and J.P. Le Formal, Results from three refraction profiles in the northern Red Sea (above $25^{\circ} \mathrm{N}$ ) recorded with an Ocean Bottom Vertical Seismic Array, Tectonophysics, 153,89-101, 1988.

Barakat, H., and P. M. Miller, Geology and Petroleum Exploration, Safaga Concession, Northern Red Sea, Egypt, in Seventh Exploration Seminar, 26 pp., Egypt. Gen. Pet. Corp., Cairo, 1984.

Bell, R.E., and A.B. Watts, Evaluation of the BGM 3 sea gravity meter system onboard R/V Conrad, Geophystcs, 51,1480-1493, 1986.

Berthelot, F., Enude thermique du Golfe de Suez dans son contexte geodynamique, Thêse de 3 eme cycle, 194 pp., Univ. Piere et Marie Curie (Paris 6), 1986.

Buck, W.R., F. Martinez, M.S. Steckler, and J.R. Cochran, Thermal consequences of lithospheric extension: Pure and simple, Tectonics, 7, 213-234, 1988.

Burrus, J., Review of geodynamic models for extensional basins: The paradox of stretching in the Gulf of Lions (Norhwest Mediterranean), Bull. Soc. Geol. Fr., 8, 377-393, 1989.

Cochran, J.R., and F. Martínez, Evidence from the northem Red Sea on the transition from continental to oceanic rifting, Tectonophysics, 153, 25-53, 1988.

Cochran, J.R., and F. Marnínez, Nucleation of seafloor spreading in a contiental rift: Influence of continental structures and initial rift geometry (abstract), Eos Trans. $A G U, 70,465,1989$.

Cochran, J.R., F. Martínez, M.S. Steckler, and M.A. Hobart, Conrad Deep: A new northem Red Sea deep. Origin and implications for continental rifting, Earth Planet. Sci. Lett., 78, 18-32, 1986.

Colletta, B., P. LeQuellec, J. Letouzey, and I. Moretti, Longinudunal evolution of the Suez rift structure (Egypt), Tectonophysics, 153, 209-220, 1988.

Courtillot, V., R. Amijo and P. Tapponnier, Kinematics of the Sinai triple junction and a twophase model of Arabia - Africa rifting, in Continental Extensional Tectonics, edited by M.P. Coward, J.F. Dewey, and P.L. Harcock, Geol. Soc. London Spec. Pub., 28, 559-573, 1987.

Diebold, J.B., et al., A large aperture seismic experiment in the Balimore Canyon Trough in The Geology of North America, vol. I-2, The Atlantic Continental Margin, edited by R.E. Sheridan, and J.S. Grow, pp. 387-398, Geological Society of America, Boulder Colo 1988 .

Gaulier, J.M., X. Le Pichon, N. Lyberis, F. Avedik, L. Geli, I. Moretti, A. Deschamps, and S. Hafez, Seismic srudy of the crustal thickness, northem Red Sea and Gulf of Suez, Tectonophysics, 153, 55-88, 1988.

Greiling, R.O., M.F. El Ramly, H. El Akhal, and RJ. Stem, Tectonic evolution of the northeastern Red Sea margin as related to basement structure, Tectonophysics. 153, 179-191, 1988.

Guennoc, R., G. Pautot, and A. Coutelle, Surficial structures of the northem Red Sea axial valley from $23^{\circ} \mathrm{N}$ to $28^{\circ} \mathrm{N}$ : time and space evolution of neo$23^{\circ} \mathrm{N}$ to $28^{\circ} \mathrm{N}$ : time and space evolution of neo1988.

Guennoc, P., G. Pautot, M.-F. Le Quentrec, and A. Coutelle, Structure of an early oceanic rift in the northern Red Sea, Oceanol. Acta, 13, 145-157. 1990.
Healy, J.H., W.D. Mooney, H.R. Blank, M.E. Gettings, W.M. Kohler, R.J. Lamson, and L.E. Leone, Saudi Arabian seismic deep-refraction Trofile: find project seport, US Geol Survey, Open File Rep. 02-37 (IR-436), 141 pp., 1982

Opey, HM Geophysical investigations in the Gulf of Suez. Consequences for the tectonic evoGulf of Suez. Consequences for the tectonic evo-
lution of the northern Red Sea. Ph.D. thesis, Kiel lution of the northem

Univ., 189 Pp.. 1985. Heffler, Some aspects of the ocean-continent transition at the continental margin of eastern North America, in Offshore Geology of Eastem Canada, Pap. Geol. Surv. Can. 74-30, 189-197, 1975.

Keen, C.E., B. de Voogd, and D. Matthews.

Conjugate margins of Canada and Europe: results from deep reflection profiling, Geology, 17,173 176, 1989.

LASE Study Group, Deep structure of the U.S. east coast passive margin from the Large Apertur Seismic Experiment (L.A.S.E.), MariPetr Geol. 3, 234-244, 1987

Le Pichon, X., and F. Barbier, Passive margin formation by low-angle faulung within the upper crust: the northern Bay of Biscay margin, Tectonics, 6, 133-150, 1987.

Le Pichon, X., and N. Chamot-Rooke, Extension of continental crust, in Proceedings of the Special Symposium on Controversies in Modern Geology edited by U. Briegel, J. McKenzie, D. Mueller and H. Weissert, pp 313-338, Academic, Troy, Mo., 1991.

Le Pichon, $\mathbf{X}$., and J.-M. Gaulier, The rotation of Arabia and the Levant fault system, Tectonophysics, 153, 271-294, 1988

Makris, J., B. Stöfen, R. Vees, A. Allam, M. Maamoun, and W. Shehata, Deep seismic soundings in Egypt: A preliminary crust and upper mantle of the Red Sea Coast, report, 9 pp, Univ. of Hamburg, 1982.

Makris, J., A. Allam, T. Moktar, A. Basahel, G.A Dehghani, and M. Bazari, Crustal structure in the northwestem region of the Arabian shield and its
transition to the Red Sea, Bull. Fac. Sci. King transition to the Red Sea, Bull. Fac.

Abdulaziz Univ., 6, 435-447, 1983.
Martínez, F., and J.R. Cochran, Structure and tectonics of the Northem Red Sea: Catching a continental margin between rifting and drifing, Tectonophysics, 150, 1-32, 1988.

Martínez, F., and J.R. Cochran, Geothenmal measurements in the northern Red Sea: Implications for lithospheric thermal structure and mode of extension during continental rifting, J. Geophys. Res., $94,12,239-12,266,1989$.

Mechie, J., C. Prodohl, and G. Koptschalitsch, Ray Mechie, J., C. Prodohl, and G. Koptschalitsch, Ray path interpretation of the crustal structure beneath 1986.

Milkereit, B., and E.R. Fluh, Saudi Arabian refraction profile: Crustal structure of the Red SeaArabian Shield transition, Tectonophysics, 111 , 283-298, 1985

Miller, P.M., and H. Barakat, Geology of the Safaga concession, northern Red Sea, Egypt, Tectonophysics, 153, 123-136, 1988.

physics, 15., M.E. Gettings, H.R. Blank, and J.H. Healy, A traveltime interpretation of the 1978 seismic refraction profile in the Kingdom of Saudi seismic refraction profile in the Kingdom of Sa

Morgan, P., C.A. Swanberg, F.A. Boulos, S.F Hennin, A.A. El-Sayed, and N.Z. Basta, Geothermal studies in Northeast Africa, Annal. Geol. Soc. Egypt, 10, 971-987, 1980

Morgan, P., F.K. Boulos, S.F. Hennin, A.A. ElSheriff, A.A. El-Sayed, N.Z. Basta, and Y.S. Melek. Heat flow in Eastern Egypt: The therma signature of a continental breakup, Jowr. of Geodyn. 4, 107-131, 1985.

Parsons, B., and J.G. Sclater, An analysis of ocean

Parsons, B., and J.G. Sclater, An analysis of Geophys. Res., 83, 803-827, 1977.

Patton, T.L., A.R. Moustafa, R.A. Nelson, and
A.S. Abdine, Tectonic evolution of the Gulf of Suez rift, in Interior rift basins, Petroleum Basin, Series, edited by J C. Harms, S.M. Landon, and M.S. Steckler, American A

Geologists, in press, 1991.

autot, G., P. Guennoc, A. Coutelle, and N. Lyberis, Discovery of a large brine deep in the

Pautot, G., P. Guennoc, A. Coutelle, and N.

Lyberis, La depression axiale du segment nord Mer Lyberis, La depression axiale du segment nord
Rouge (de $25^{\circ} \mathrm{N}$ à $28^{\circ} \mathrm{N}$ ): Nouvelles données géologiques et géophysıques obtenues au cours de la campagne TRANSMEROU 83, Bull. Soc. Geol. Fr., 8, 381-399, 1986

Pinet, B., L. Montadert, A. Mascle, M. Cazes, and C. Bois, New insights on the structure and the formarion of sedimentary basins from seismic profiling in Westem Europe, in Petroleum Geology of NW Europe edited by J. Brooks, and $\mathrm{K}$ Glennee, pp 11-31, Graham and Trotman, Glennee, pp 11

Prodehl, C., Interpretation of a seismic-refraction survey across the Arabian shield in westem Saudi Arabia, Tectonophysics, 111, 247-282, 1985.

Rihm R. and J. Makris, Asymetric strucure in the northern Red Sea - Consequence of shear-movement along the Dead Sea fault (abstract) Ann. Geophys., spec. issue, p. 88, 1989.

Steckler, M.S., and U.S. ten Brink, Lithospheric strength variations as a control on new plate boundaries: Examples from the northem Red Sea regions, Earth Planet. Sci. Lett., 79, 120-132 1986

Steckler, M.S., F. Berthelot, N. Lyberis, and X. Le Pichon, Subsidence in the Gulf of Suez: Implic tions for rifting and plate kinematics, Tectonophysics, 153, 249-270, 1988.

Stern, R.J., and CE. Hedge, Geochronologic and isotropic constraints on Late Precambrian crustal evolution in the Eastem Desert of Egypt, Geology, 12, 168-172, 1985 .

Stern, R.J., D. Gonfred, and C.E. Hedge, Late Precambrian rifting and crustal evolution in the Northeastem Desern of Egypt, Geology, 12, 168$172,1984$.

Talwani, M., J.L. Worzel, and M. Landisman, Rapid gravity computations for two-dimensional bodies with apphication to the Mendicino submarine fracture zone, J Geophys. Res., 64, 49-59, 1959.

Talwani, M., J. Mutter, R. Houtz, and M. König, The crustal structure and evolution of the area underlying the magnetic quiet zone on the margin south of Australia, in Geological and Geophysical Investigations of Contnnental Margins, edited by J.S. Watkins, L. Montadert, and P.W. Dickerson, pp. 151-175, American Association of Petroleum Geologists, Tulsa, Okla, 1979.

Tewfik, N., and M. Ayyad, Petroleum exploration in the Red Sea shelf of Egypt, in Sixth Exploration Seminar, 30 pp., Egypt. Gen. Pet. Corp., Cairo, 1982.

Weigel, W., G. Wissman, and P. Goldflam, Deep seismic structure (Mauritania and central Morocco), in Geology of the Northwest African Continental Margin, edited by U. Van Rad, K. Hinz, M. Margin, edited by
Ferthein, and E. Siebold, pp. 132-158, Springer-

J. R. Cochran, Lamont-Doherty Geological Observatory of Columbia University, Palisades, NY, 10964, USA.

J.-M. Gaulier, Instıtut Francais du Petrole, B.P.

311, 92507 Rueil Malmaison, France.

$X$. Le Pichon, Département de Géologie, URA

1316. Ecole Normale Supérieure, 24, rue

Lhomond,75005 Paris, France.

(Received July 19, 1990;

revised March 21, 1991; 